\title{
A mountain of millipedes VI. New records, new species, a new genus and a general discussion of Odontopygidae from the Udzungwa Mts, Tanzania (Diplopoda, Spirostreptida, Odontopygidae)
}

\author{
Henrik ENGHOFF \\ Natural History Museum of Denmark, University of Copenhagen, \\ Universitetsparken 15, DK-2100 Copenhagen Ø, Denmark. \\ Email: henghoff@snm.ku.dk \\ urn:1sid:zoobank.org:author:FB09A817-000D-43C3-BCC4-2BC1E5373635
}

\begin{abstract}
Damacornu gen. nov. (type species: D. transversum gen. et sp. nov.), Geotypodon papei sp. nov. and Spinotarsus fortehamatus sp. nov. are described, and Helicochetus dimidiatus (Peters, 1855), H. mutaba Kraus, 1960 and Hoffmanides dissutus (Hoffman, 1963) are recorded from the Udzungwa Mts, Tanzania. A complete overview of the 39 odontopygid species now known from the Udzungwa Mts is given, including notes on endemism, biogeographical relationships and altitudinal distribution patterns.
\end{abstract}

Keywords. Eastern Arc, taxonomy, endemism, altitudinal distribution.

Enghoff H. 2018. A mountain of millipedes VI. New records, new species, a new genus and a general discussion of Odontopygidae from the Udzungwa Mts, Tanzania (Diplopoda, Spirostreptida, Odontopygidae). European Journal of Taxonomy 394: 1-29. https://doi.org/10.5852/ejt.2018.394

\section{Introduction}

The very rich fauna of odontopygid millipedes from the Udzungwa Mts has been the subject of five recent papers (Enghoff 2014, 2016a, 2016b, 2016c; Enghoff \& Frederiksen 2015). The present contribution deals with the remaining Udzungwa odontopygids in the very large collections of Tanzanian millipedes in the Natural History Museum of Denmark and the Virginia Museum of Natural History (but see note on the genus Aquattuor Frederiksen, 2013). Three new species are described, one of them belonging to a new genus, and three previously described species are recorded for the first time from the Udzungwa Mountains. The collecting sites for the treated species are shown in Fig. 1. A list of the known odontopygid fauna of the Udzungwa Mountains, now comprising 39 species, is included, as well as notes on distribution and endemicity.

\section{Material and methods}

The material described in this paper derives from the zoological collections of the Natural History Museum of Denmark, University of Copenhagen (ZMUC) and the Virginia Museum of Natural History (VMNH). Methods of study are as in the previous papers in this series, as detailed by Enghoff (2014). 


\section{Abbreviations for morphological terms used in the descriptions and on illustrations}

$$
\begin{array}{ll}
a p & =\text { angular process of metaplica } \\
b l a & =\text { basal lamella of telomere } \\
b p & =\text { apical basad process of coxa } \\
b t l & =\text { basal lamella of telomere } \\
c u & =\text { cucullus } \\
e l 1, \text { el2 } & =\text { smooth telomeral lamellae } \\
k n & =\text { knob-like turn of solenomere } \\
l d & =\text { lateral denticle of coxa } \\
m f & =\text { metaplical flange } \\
m l p & =\text { metaplical lamellar process } \\
m m f & =\text { mesal metaplical flange } \\
m p & =\text { metaplica } \\
m r 1, m r 2 & =\text { metaplical ridges } \\
m s & =\text { metaplical shelf } \\
m s p & =\text { metaplical spine-like process }
\end{array}
$$

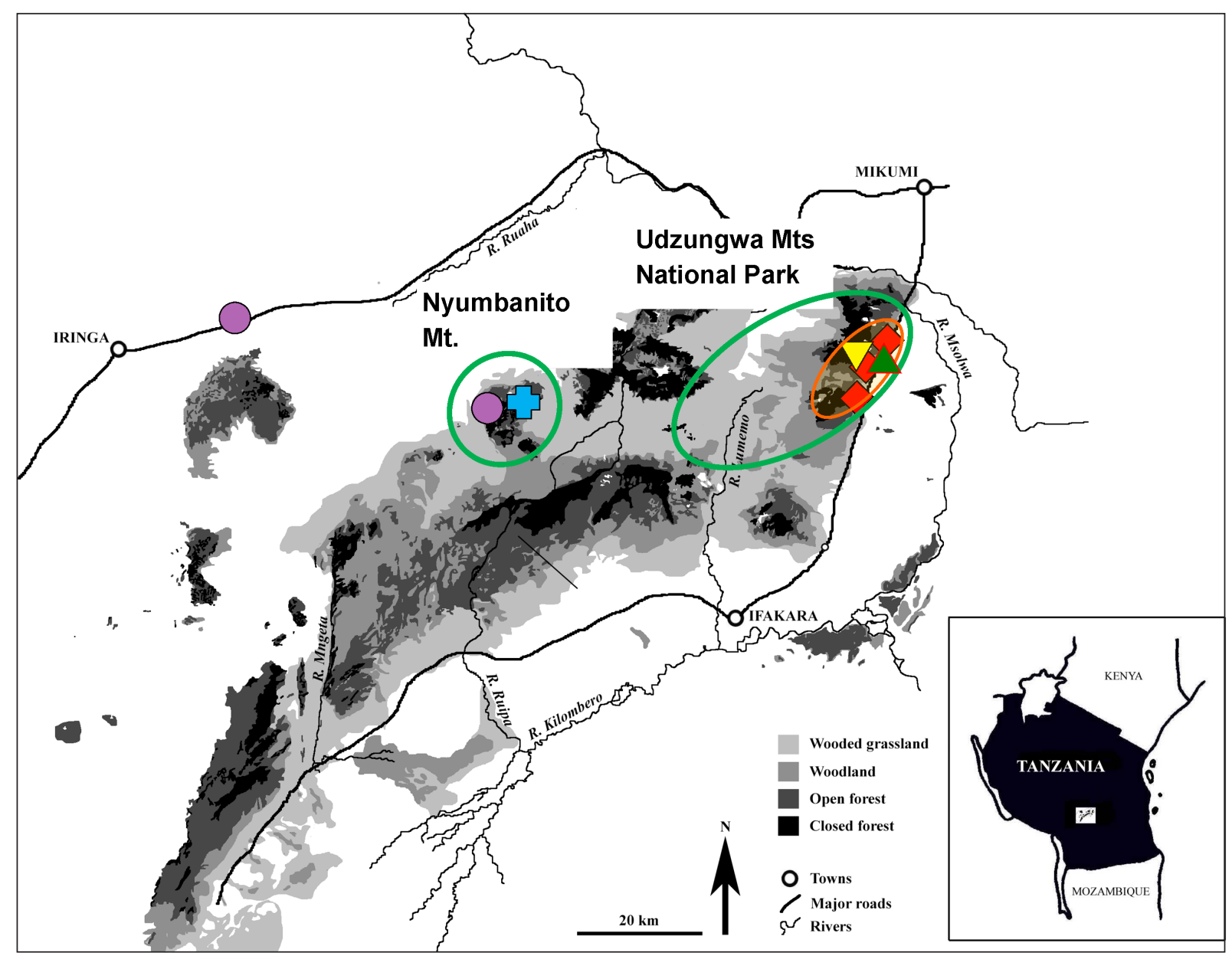

Fig. 1. Map of the Udzungwa Mts, showing the collecting sites for the treated species. Blue cross = Damacornu transversum gen. et sp. nov.; red diamonds = Geotypodon papei sp. nov.; yellow triangle = Helicochetus dimidiatus (Peters, 1855); purple dots =H. mutaba Kraus, 1960; orange oval = Hoffmanides dissutus (Hoffman, 1963) (approximate location); green triangle = Spinotarsus fortehamatus sp. nov. Based on Marshall et al. (2010: fig. 1). 


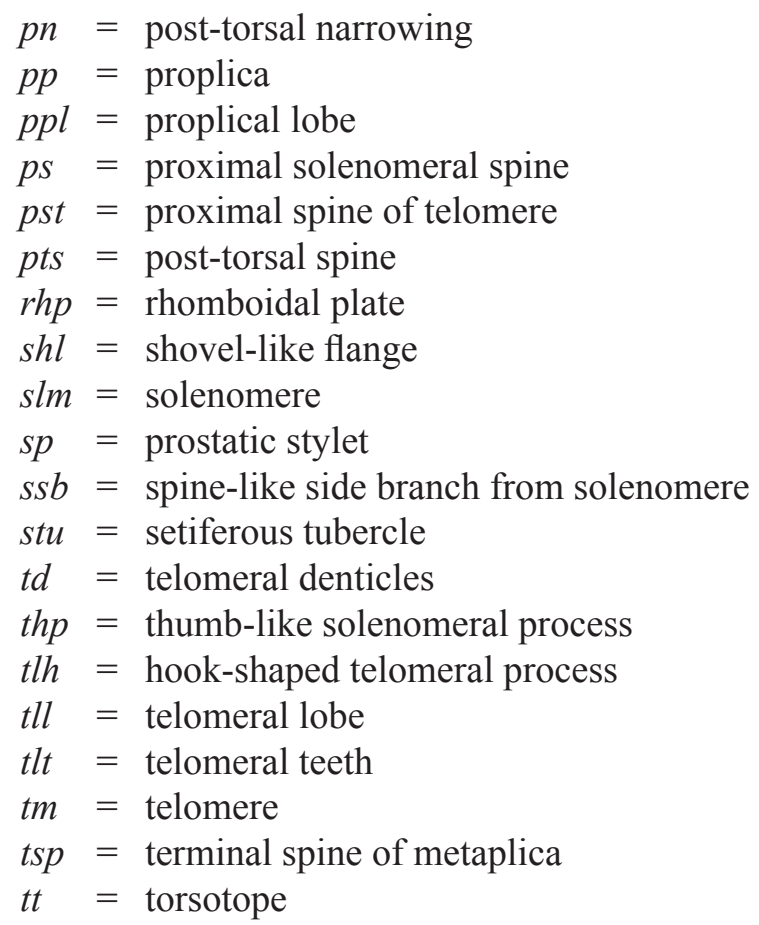

\title{
Other abbreviations used in the text
}

a.s.l. = above sea-level

$\mathrm{KMH}=\mathrm{Kim}$ M. Howell collection code

$\mathrm{VMNH}=$ Virginia Museum of Natural History

ZMUC = Natural History Museum of Denmark (Zoological Museum)

\section{Taxonomy}

\author{
Class Diplopoda de Blainville in Gervais, 1844 \\ Order Spirostreptida Brandt, 1833 \\ Family Odontopygidae Attems, 1909 \\ Subfamily Archepyginae Manfredi, 1939 \\ Tribe Prionopetalini Hoffman, 1991
}

Genus Aquattuor Frederiksen, 2013

Aquattuor Frederiksen, 2013: 64.

A considerable new collection of Aquattuor spp. from the Udzungwa Mts has recently been acquired by the ZMUC, the treatment of which awaits a renewed study of the genus by Sara Frederiksen.

Genus Damacornu gen. nov.

urn:1sid:zoobank.org:act:6D078904-52C2-43CF-9930-050C487442DA

\section{Type species}

Damacornu transversum gen. et sp. nov., by original designation.

\section{Other included species}

None. 


\section{Diagnosis}

A genus of Odontopygidae-Prionopetalini characterized by the following combination of characters: gonopod coxa with a mesal spineless metaplical shelf, without a basad metaplical spine; telopodital torsotope with a long spine; solenomere whip-like, with a basal spine but otherwise without outgrowths, apically fluted and spiraled; telomere a longitudinally folded lamella; distal half of telomere bent at right angles in relation to basal half, with a row of teeth on internal surface.

\section{Etymology}

A composite noun, from Dama (fallow deer) and cornu (horn, antler), referring to the (slight) resemblance between the gonopod telomere and an antler from the fallow deer, Dama dama (Linnaeus, 1758). Gender neuter.

\section{Remarks}

In the key to genera of "Odontopyginae" by Kraus (1966), Damacornu transversum gen. et sp. nov. keys out to the genus Odontopyge, and in the key to species of "Odontopyge" by Kraus (1960) it keys out in couplet 11 (“O." citernii Silvestri, 1898 and "O." difficilis Silvestri, 1895). The new species is, however, clearly different from these two species in which there is no metaplical shelf and the proximal solenomeral spine (ps) ("Tibialdorn") is rudimentary. None of the "orphaned" species assigned to Odontopyge by earlier authors (see Enghoff 2016a) can be adopted by Damacornu gen. nov., which for the time being remains monotypic.

\section{Damacornu transversum gen. et sp. nov. urn:1sid:zoobank.org:act:4B0BC420-38E0-492E-85DC-0879E83BCDA7}

Fig. 2

\section{Diagnosis}

See generic diagnosis (genus monotypic).

\section{Etymology}

The name is a Latin adjective and refers to the transverse yellow markings on the body rings.

Material studied (total: 1 đ)

\section{Holotype}

TANZANIA: ${ }^{\Uparrow}$, Iringa Region and District, Ndekwa village, Mt Nyumbenito, Udzungwa Mountains, 1400 m a.s.l., 4 Apr. 1982, Jan Kielland leg. (VMNH).

\section{Description}

\section{Male}

SizE. Length ? (broken). Body diameter $6.4 \mathrm{~mm}$. 60 podous body rings, no apodous rings in front of telson.

CoLour. After 35 years in alcohol blackish, anterior part of head and posterior part of metazona amber; a transverse yellow band on prozona extending from midline ca. halfway down to ozopores; legs yellow.

HEAD. Without peculiarities. Four supralabral setae.

Collum. With a marginal furrow, followed by two abbreviated and one complete submarginal furrow. 

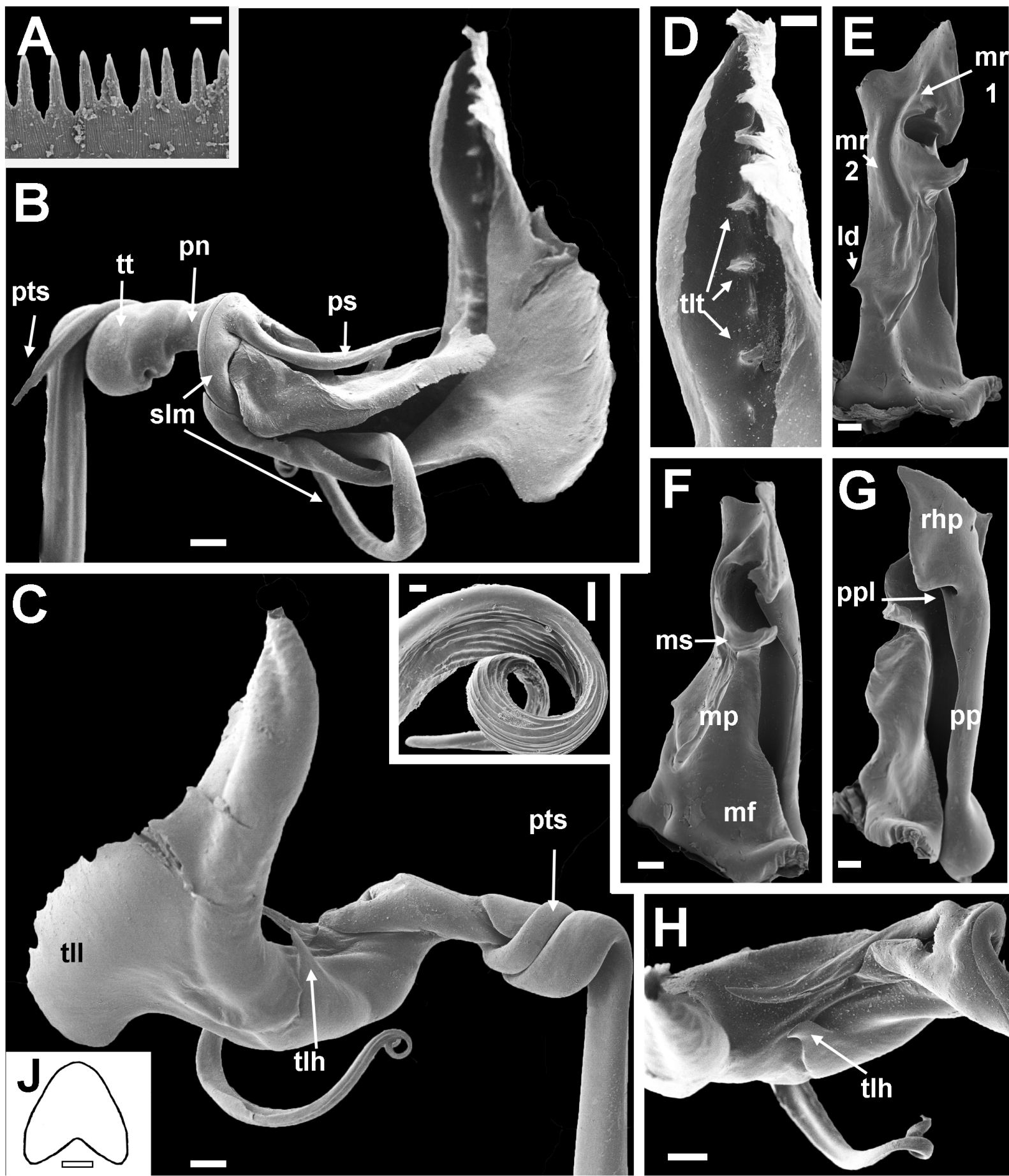

Fig. 2. Damacornu transversum gen. et sp. nov., holotype. A. Limbus. B-I. Right gonopod. B. Telopodite, posterior view. C. Telopodite, anterior view. D. Terminal process of telomeral lamella, posterior view. E. Coxa, posterior view. F. Coxa, mesal view. G. Coxa, anterior, slightly mesal view. H. Basal part of telomere, ventral view. I. Tip of solenomere. J. Sternum of rudimentary ninth leg-pair. Abbreviations: $l d=$ lateral denticle of coxa; $m f=$ metaplical flange; $m p=$ metaplica; $m r l, m r 2=$ metaplical ridges; $m s=$ metaplical shelf; $p n=$ post-torsal narrowing; $p p=$ proplica; $p p l=$ proplical lobe; $p s=$ proximal solenomeral spine; $p t s=$ post-torsal spine; $r h p=$ rhomboidal plate; $\operatorname{slm}=$ solenomere; $t$ th $=$ hook-shaped telomeral process; $t l l=$ telomeral lobe; $t l t=$ telomeral teeth; $t t=$ torsotope. Scale bars: $\mathrm{A}=0.01 \mathrm{~mm}$; $\mathrm{B}-\mathrm{C}, \mathrm{E}-\mathrm{H}=0.2 \mathrm{~mm} ; \mathrm{D}=0.1 \mathrm{~mm} ; \mathrm{I}=0.02 \mathrm{~mm} ; \mathrm{J}=0.5 \mathrm{~mm}$. 
BoDY RINGS. Almost perfect cylinders, not vaulted; suture straight; ozopores starting from ring 6, placed $\mathrm{ca}^{1 / 3}$ of metazona length behind suture. 18-22 metazonital striae reaching up to ca one metazonite length below ozopore.

ANAL VALVES. With a well-developed dorsal tooth and a small ventral one; margin barely raised, setiferous tubercles inconspicuous.

Limbus (Fig. 2A). Divided into simple, pointed teeth, each tooth $>3$ times longer than broad.

MaLe Legs. With adhesive pads on postfemur and tibia.

Gonopod coxa (Fig. 2E-G). Proplica ( $p p$ ) (Fig. 2G) narrow, parallel-sided, ending in a small proplical lobe $(p p l)$, distal to $p p l$ continuing as a large, irregularly rhomboidal plate $(r h p)$; disto-mesal corner of $r h p$ drawn out into blunt triangular process. Metaplica $(\mathrm{mp})$ with large metaplica flange $(\mathrm{mf})$ covering base of proplica in mesal view (Fig. 2F), with bowl-shaped shelf ( $m s$ ) slightly basal to level of proplical lobe, distal margin of shelf continuing distad as longitudinal ridge $(\mathrm{mrl})$; another longitudinal ridge $(\mathrm{mr} 2)$ parallel to $\mathrm{mrl}$, close to lateral margin of coxa; a small denticle (ld) on lateral margin ca $1 / 3$ from base (Fig. 2E); lateral surface of coxa concave.

Gonopod telopodite (Fig. 2B-D, H-I). Arculus $90^{\circ}$. Torsotope $(t t)$ simple, compact, with a long spine (pts, "Femoraldorn" sensu Kraus 1960, "Praefemoraldorn" sensu Kraus 1966) (Fig. 2B-C). Post-torsal narrowing ( $p n)$ pronounced, without processes or spines (Fig. 2B). Telopodite just distal to post-torsal narrowing dividing into slender, whip-like solenomere and lamellate telomere. Solenomere $(\mathrm{slm})$ (Fig. 2B) with a long, straight basal spine (ps), otherwise without any outgrowths, apically fluted and spiraled (Fig. 2I). Telomere consisting of a single, longitudinally folded lamella. Proximal half of telomere roughly parallel-sided, continuing in same direction as torsotope and post-torsal narrowing; a small hook-shaped process $(t l h)($ Fig. $2 \mathrm{C}, \mathrm{H}$ ) originating from anterior external surface; distal half of telomere set off by $90^{\circ}$ angle, posterior margin of distal half first forming large rounded lobe $(t l l)$ (Fig. 2C), in distal part irregularly serrate; a row of coarse teeth $(t t t)$ on internal surface of terminal process of telomeral lamella (Fig. 2D).

SteRnUM OF RUdimENTARY NINTH LEG-PAIR (Fig. 2J). Heart-shaped.

\section{Female}

Unknown.

\section{Distribution}

Known only from Mt. Nyambanito (Nyumbenito), 1400 m a.s.l.

Genus Geotypodon Enghoff, 2016

Geotypodon Enghoff, 2016a: 6.

\section{Type species}

Geotypodon millemanus Enghoff, 2016, by original designation.

\section{Other included species}

Geotypodon papei sp. nov. and 20 further species, see Enghoff (2016a).

\section{Diagnosis}

(From Enghoff 2016a, slightly modified.) A genus of Odontopygidae-Prionopetalini characterized by: a long basad metaplical spine on the anterior side of the coxa; a compact torsotope; lack of pretorsal or 
torsal spines/processes; a pronounced post-torsal narrowing without spines; a division of the telopodite into solenomere and telomere immediately distal to post-torsal narrowing; a spine emerging from the base of the telomere; a slender, whip-like, smooth solenomere without any outgrowths or appendages (except sometimes a tiny subapical spine); a telomere consisting of various lobes and lamellae with largely smooth margins.

\section{Geotypodon papei sp. nov. urn:1sid:zoobank.org:act:3D36FD3A-B534-422E-8354-D0EDCAB2A748}

Fig. 3

\section{Diagnosis}

Differs from all other species of Geotypodon, except. G. carli (Kraus, 1960), by the combination of a very long, slender metaplical spine and a relatively simple telomere mainly consisting of a longitudinally folded sheet. Differs from G. carli by the shape of the basad, metaplical, spine-like process (spine strongly expanded in basal part in G. papei sp. nov., not so in G. carli). See also Table 1.

\section{Etymology}

The name honours Thomas Pape, collector of the holotype and a leading figure in the Eastern Arc program of the Natural History Museum of Demark.

Material studied (total: $3 \stackrel{\jmath}{\curvearrowright}$ )

\section{Holotype}

TANZANIA: $\partial^{\lambda}$, Morogoro Region,UdzungwaMountains National Park, SanjeChiniCamp, $07^{\circ} 46^{\prime} 24.6^{\prime \prime} \mathrm{S}$, 36 53'47.7" E, 598 m a.s.1., 17-19 Jan. 2014, T. Pape leg. (ZMUC).

\section{Paratypes}

TANZANIA: 1 `, Morogoro Region, Udzungwa Ecological Monitoring Centre, Mang'ula, $07^{\circ} 50^{\prime} 44.9^{\prime \prime} \mathrm{S}$, 36 53'28.2" E, 339 m a.s.1., 18-20 Jan. 2014, T. Pape and N. Scharff leg. (ZMUC); 1 ơ, Morogoro Region, Udzungwa Mountains National Park, Kidatu, Plot 1, 07²41'13.8' S, 365 56'28.6" E, 650 m a.s.l., 24 Oct. 2014, pitfall trap. J. Malumbres-Olarte leg. (ZMUC).

\section{Description}

\section{Male}

SizE. Length 5-6 cm, diameter 4.5-4.6 mm, 53-55 podous rings, no apodous rings in front of telson.

CoLour. After 3 years in alcohol, head reddish brown to dark brown, antennae dark brown, collum, body rings and telson dark grey without contrasting markings, posterior $1 / 4$ of metazona amber, legs reddish brown.

HEAD. Without peculiarities. Seven or eight supralabral setae.

CoLLum. With a marginal and two submarginal furrows.

BoDY RINGS. Almost perfect cylinders, not vaulted; suture straight; ozopores starting from ring 6, placed midway between suture and limbus. 13-15 metazonital striae, reaching up to ca one metazonite length below ozopore.

ANAL VALVES. Each with a stout dorsal spine; ventrally slightly angular; margins raised; each valve with three marginal setae not borne on tubercles. 

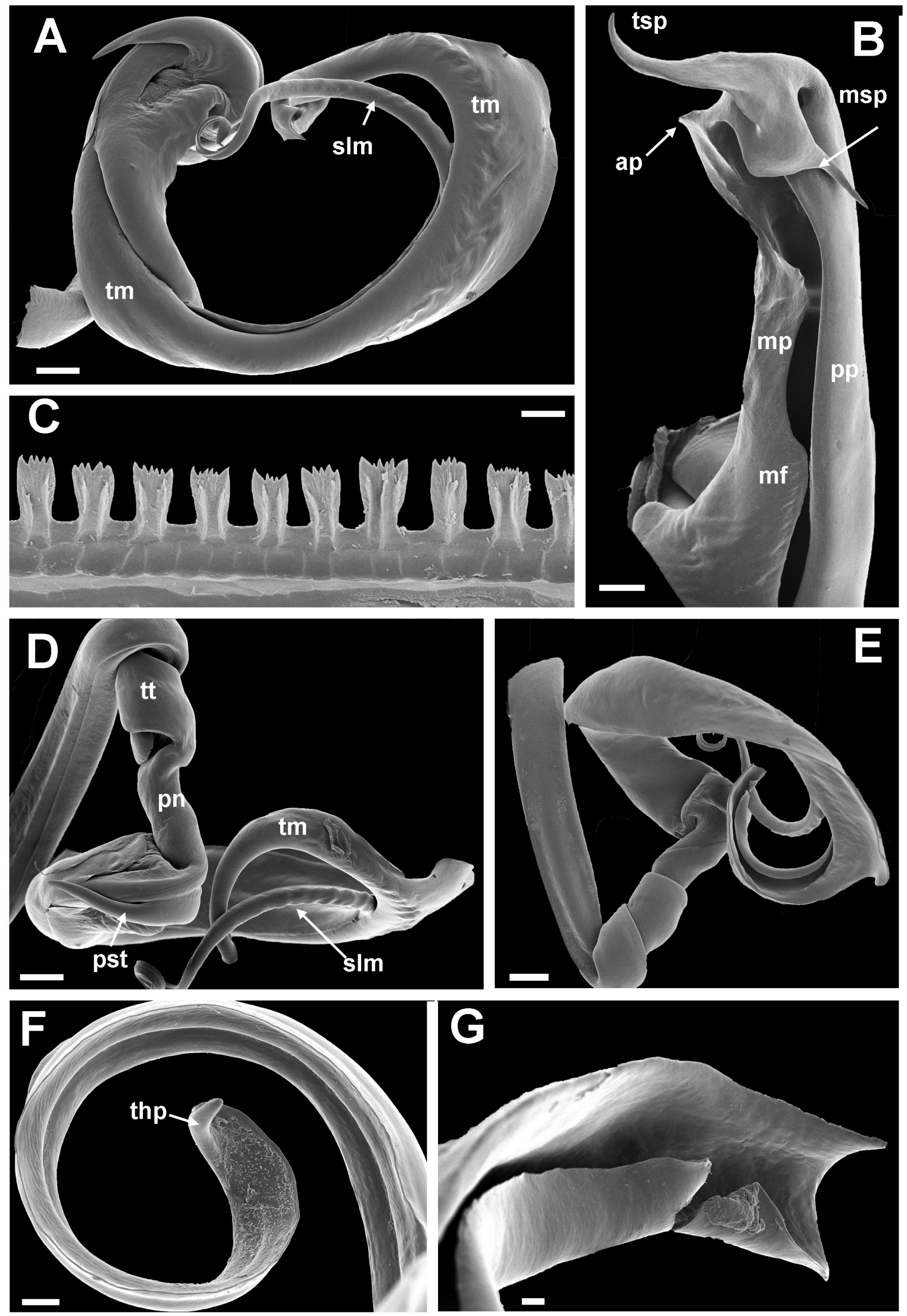
Limbus (Fig. 3C). Consisting of isolated hand-like lobes with a length of ca $10 \mu \mathrm{m}$, each with 5-9 'fingers' and each with two ridges running along its length.

MALE LEGS. With tiny postfemoral ventral pads from leg-pair 3-5, from leg-pair 6 postfemoral pads large, covering entire podomere, but gradually smaller posteriorly before disappearing completely shortly before posterior end. Tibiae with tiny ventral pads from leg-pair 3 until somewhere between gonopods and mid-body.

Gonopod coxa (Fig. 3B). Slender, almost parallel-sided. Proplica $(p p)$ simple, ending in small proplical lobe hidden from view by metaplical spinelike process $(m s p)$. Metaplica $(m p)$ with small, basal, anteriad flange $(\mathrm{mf})$; subdistally with angular process $(a p)$; distally terminating in very long, slender, sigmoid spine ( $t s p)$; on anterior side with long, pointed, basally expanded, basad spine-like process ( $m s p$ ).

Gonopod telopodite (Fig. 3A, D-G). Arculus 90 . Torsotope ( $t t$ ) simple, without processes (Fig. 2D). Post-torsal narrowing ( $p n)$ not very pronounced, yet distinct (Fig. 2D). Telopodite just distal to posttorsal narrowing dividing into simple, slender solenomere and equally long, narrow, almost parallelsided telomere. Solenomere $(\mathrm{slm})$ resting in curvature of telomere (Fig. 3A, D), terminally taeniate, with thumb-like process $(t h p)$ at very tip (Fig. $3 \mathrm{~F}$ ). Telomere $(\mathrm{tm})$ with stout, curved proximal spine ( $p s t)$ (Fig. 2D); main body of telomere a long, parallel-sided sheet, folded longitudinally and then curved in almost complete circle, abruptly narrower at $\mathrm{ca}^{2} / 3$ of its length (Fig. 3D-E, G).

\section{Female}

Unknown.

\section{Remarks}

In the genus key of Kraus (1966), Geotypodon papei sp. nov. easily keys out in the last couplet (33), where the choice is between Patinatius Attems, 1928 and Odontopyge Brandt, 1841. In the couplet, the two genera are distinguished by Patinatius having the "Lateralblatt" prolonged into a cone or extended into a long spine vs Odontopyge not having such modifications. Couplet 33 in Kraus (1966) is copied from couplet 33 in Kraus (1960) with the difference that in the 1960 version, this couplet separates Odontopygista Kraus, 1960 from Odontopyge. Kraus (1966) synonymised Odontopygista with Patinatius. In both versions of couplet 33, Kraus made an error because the part of the gonopod coxa that has a cone- or spine-like outgrowth is the metaplica, which in Kraus' terminology is the "Medialblatt" (as also used in his genus and species descriptions). This aside, one might argue that the long, sigmoid terminal spine (tsp) could be the homologue of such a "long spine", but Geotypodon papei sp. nov. disagrees with the definition of Patinatius in several respects, including the limbus (spatulate and multicusped in Geotypodon papei sp. nov., rounded lobes in Patinatius), the internal surface of the telomere (smooth in Geotypodon papei sp. nov., with a row of denticles in Patinatius) and the tip of the solenomere ("thumb and lamella" in Geotypodon papei sp. nov., simply pointed in Patinatius). Geotypodon papei sp. nov. therefore keys out to Odontopyge in Kraus'keys, and as explained by Enghoff (2016a) this generic name is not available for other than a small group of species very different from Geotypodon papei sp. nov. In the key to species of "Odontopyge" in Kraus (1960), Geotypodon papei

Fig. 3 (page 8). Geotypodon papei sp. nov., holotype. A-B, D-G. Right gonopod. A. Telopodite, mesal view. B. Coxa, anterior view. D. Telopodite, posterior view. E. Telopodite, anterior view. F. Tip of solenomere. G. Tip of telomere. C. Limbus. Abbreviations: $a p=$ angular process of metaplica; $m f=$ metaplical flange; $m p=$ metaplica; $m s p=$ metapical spine-like process; $p n=$ post-torsal narrowing; $p p=$ proplica; $p s t=$ proximal telomeral spine; $\operatorname{slm}=$ solenomere; $t h p=$ thumb-like solenomeral process; $t m=$ telomere; $t s p=$ terminal spine of metaplica; $t t=$ torsotope. Scale bars: A-B, D-E $=0.2 \mathrm{~mm}$; $\mathrm{C}=0.01 \mathrm{~mm} ; \mathrm{F}-\mathrm{G}=0.02 \mathrm{~mm}$. 
Table 1. Comparison of Geotypodon papei sp. nov. with G. carli (Kraus, 1960).

\begin{tabular}{ccc}
\hline & G. papei & G. carli (data from Kraus 1960) \\
\hline Podous body rings & $53-55$ & 61 ("62 Segmente") \\
Diameter & $4.5-4.6 \mathrm{~mm}$ & $4.6 \mathrm{~mm}$ \\
Supralabral setae & $7-8$ & 4 \\
Metazonital striae & $13-16$ & $\approx 6$ \\
Metaplical spine-like process & with a large mesad lobe at base & without a basal lobe \\
Telomere & abruptly narrower at ca 2/3 of length & gradually a little narrower towards end \\
Solenomere & tip apparently with "finger”, & simple, according to drawing \\
& as in Fig. 3F, but difficult to see & \\
Provenance & Tanzania: Udzungwa Mountains & Democratic Republic of the Congo: Kivi, \\
& National Park, 339-650 m a.s.l. & Kabare, Fizi M'Boko, 800 m a.s.l. \\
\hline
\end{tabular}

sp. nov. smoothly keys out to carli Kraus, 1960, one of the species that was transferred to Geotypodon by Enghoff (2016a), and the two species are indeed very similar. There are, however, enough differences to regard them as separate species, cf. Table 1.

\section{Distribution}

Known from three sites in the northeastern part of the Udzungwa Mts, at moderate altitudes (339-650 m a.s.1.).

Genus Helicochetus Attems, 1909

Helicochetus Attems, 1909a: 158.

\section{Type species}

Spirostreptus dimidiatus Peters, 1855, by original designation. See further below.

\section{Other included species}

Helicochetus aberrans Kraus, 1966 (Zambia), H. digititarsus Kraus, 1957 (Democratic Republic of the Congo, Tanzania), H. electricus Kraus, 1958 (Democratic Republic of the Congo), H. gregorii (Pocock, 1896) (Kenya), H. inversus Kraus, 1958 (Democratic Republic of the Congo), H. involutus Attems, 1935 (Democratic Republic of the Congo), H. laciniatus Attems, 1935 (Democratic Republic of the Congo), H. levifolius Attems, 1914 ("Sambesi", Mozambique), H. monodon Kraus, 1960 (Zambia), H. mutaba Kraus, 1960 (Democratic Republic of the Congo), H. pococki (Carl, 1909) (Tanzania), H. rarus Kraus, 1958 (Democratic Republic of the Congo).

Kraus (1960) provided an identification key to the species, except $H$. aberrans.

\section{Remarks}

The material from the Udzungwa Mts includes specimens of two species of Helichochetus. Separate descriptive notes are given for each species, but two characters shared by both species may prove to be genus-characteristic and are therefore commented on here.

Limbus (Fig. 4A, C, E). Kraus (1960) characterized the limbus of Helichochetus (translated from German): "Limbus divided by rounded indentations into processes which each carry three to six nail-like points. Limbus very broad, ca. $10 \times$ as broad as the processes, with a silky sheen due to the characteristic surface 
sculpture (exception H. laciniatus)". The limbus of the two studied species, especially H. mutaba, is indeed very broad (Fig. 4A, C), and the processes and nail-like points agree fully with Kraus' description. It is not clear from his publications (Kraus 1960, 1966) what he meant by the "characteristic surface structure". The SEM images (Fig. 4A, C, E) provide no clue. There is, however, another remarkable detail, visible in Fig. 4E: under the limbus proper, there is a "sub-limbus" consisting of rounded, almost semicircular lobes.

Cytoscute denticles (Fig. 4B, D, F). The "cytoscutes", i.e., cuticular "cells" each corresponding to a hypodermis cell (Fusco et al. 2000) very often carry a row of tiny denticles along one edge. In both studied species of Helicochetus, these denticles are much larger than normal and point away from the cuticular surface rather than lying parallel to it.

Helicochetus dimidiatus (Peters, 1855)

Figs 4A-B, 5

Spirostreptus dimidiatus Peters, 1855: 79.

Helicochetus dimidiatus - Attems (1909a): 158.

Material studied (total: 1 ふ)

TANZANIA: $1 \partial^{\wedge}$, Morogoro Region, Udzungwa Ecological Monitoring Centre, Mang'ula, 07 $50^{\prime} 44.9^{\prime \prime} \mathrm{S}$, 3653'28.2" E, 339 m a.s.1., 20 Mar. 2013, T. Pape and N. Scharff leg. (ZMUC).

\section{Description}

\section{Male}

Based on studied specimen. Details from previous descriptions in parentheses.

Size. Diameter $5.4 \mathrm{~mm}, 59$ podous rings, no apodous rings in front of telson. (Peters 1855: length 65-60 mm; diameter 5-5.5 mm; 62 "annuli"; Peters 1862: length $60-70 \mathrm{~mm}$; diameter $5 \mathrm{~mm}$; 66 body rings; Verhoeff 1901, §, as Odontopyge attemsi Verhoeff, 1901: length $62 \frac{1}{2} \mathrm{~mm}$; 61 body segments.)

Colour. After 4 years in alcohol greyish; head, antennae, legs, and posterior ca $40 \%$ of metazonites yellowish.

HEAD. Without peculiarities. Supralabral setae not countable due to damage. (Peters 1855, 1862: 6-7; Verhoeff 1901: 5; Attems 1914: 6.)

Collum. With two complete furrows on each side, none of them marginal. (Peters 1855: a marginal and two further striae; Verhoeff 1901: four striae; Attems 1914: a marginal ridge, then an incomplete, and then two complete striae.)

BoDY RINGS. Almost perfect cylinders, not vaulted; suture straight; ozopores starting from ring 6, placed ca $1 / 3$ of metazonite length between suture and limbus. Ca 13 metazonital striae reaching almost up to ozopore. Surface microsculpture (Fig. 4B), see Remarks for genus.

ANAL VALVES. Each with a moderate dorsal spine; margins raised; each valve with three marginal setae not borne on tubercles.

Limbus (Fig. 4A). See Remarks for genus.

MaLe Legs. With postfemoral ventral pads from first post-gonopodal leg-pair 3-5 until ca midbody; anteriormost and posteriormost pads small, intermediate ones covering entire ventral side of postfemur. 
Gonopod coXa (Fig. 5A-D). As typical for the genus, including small, distal basad process ( $b p$ ) (Fig. 5B, D). Prostatic stylet $(s p)$ visible in coxal cavity (Fig. 5B-C).

Gonopod telopodite (Fig. 5E-H). Tip of solenomere ( $\operatorname{sim}$ ) tightly spiraled (like a corkscrew) (Fig. 5H); no processes visible in spiral. Telomere $(\mathrm{tm})$ ending in long, slender process with a terminal brush of long fringes (Fig. 5F-G).
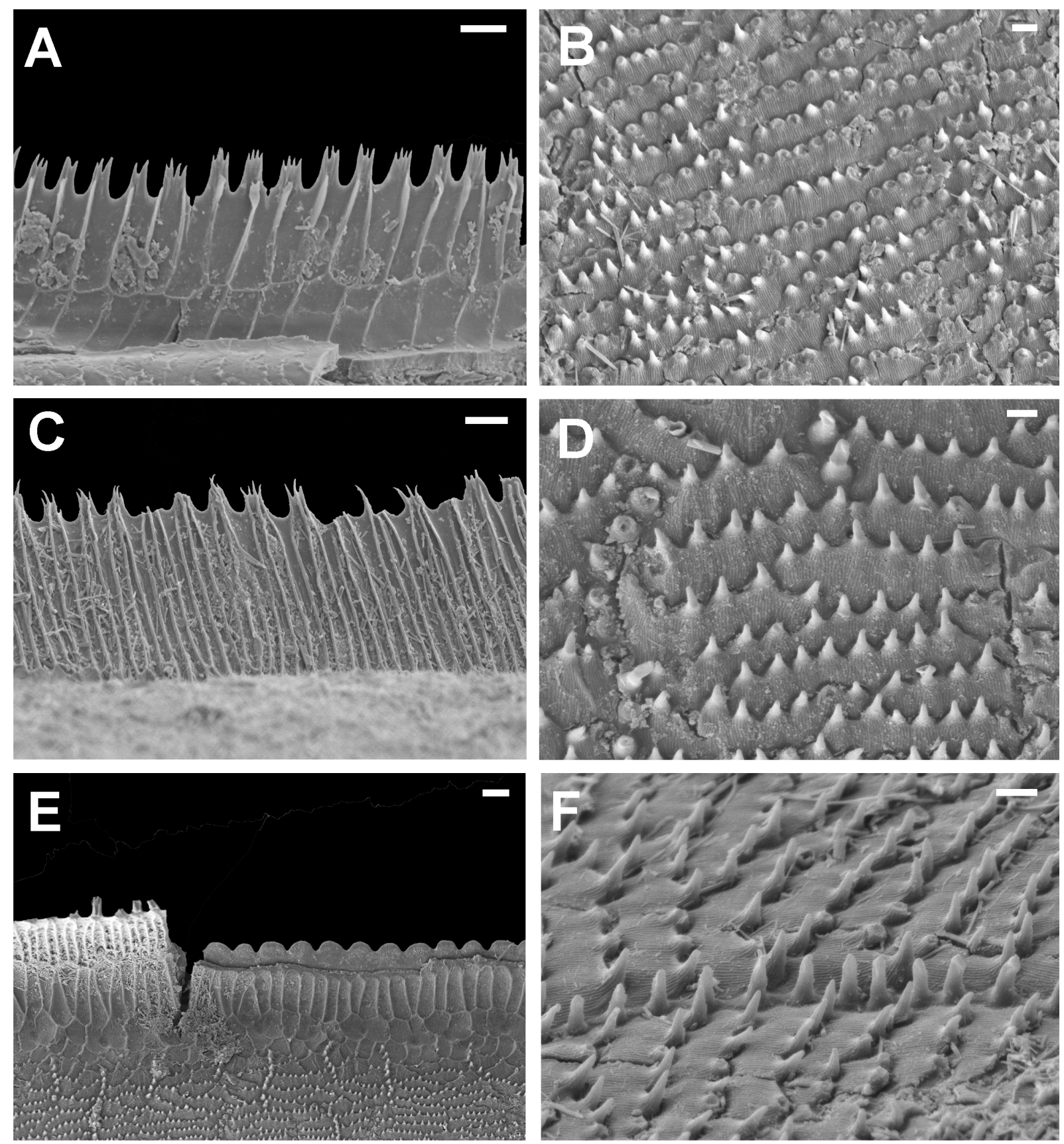

Fig. 4. Helicochetus spp., $\lesssim \widehat{~}$, from Udzungwa Mts. A-B. H. dimidiatus (Peters, 1855). C-F. H. mutaba Kraus, 1960. A, C, E. Limbus; in E the limbus proper is damaged (remains are seen to the left), so the round-lobed "sublimbus" becomes visible. B, D, F. Surface microsculpture of limbus. Scale bars: A, C, $\mathrm{E}=0.01 \mathrm{~mm} ; \mathrm{B}, \mathrm{D}, \mathrm{F}=0.002 \mathrm{~mm}$. 
ENGHOFF H., Odontopygid millipedes from the Udzungwa Mts
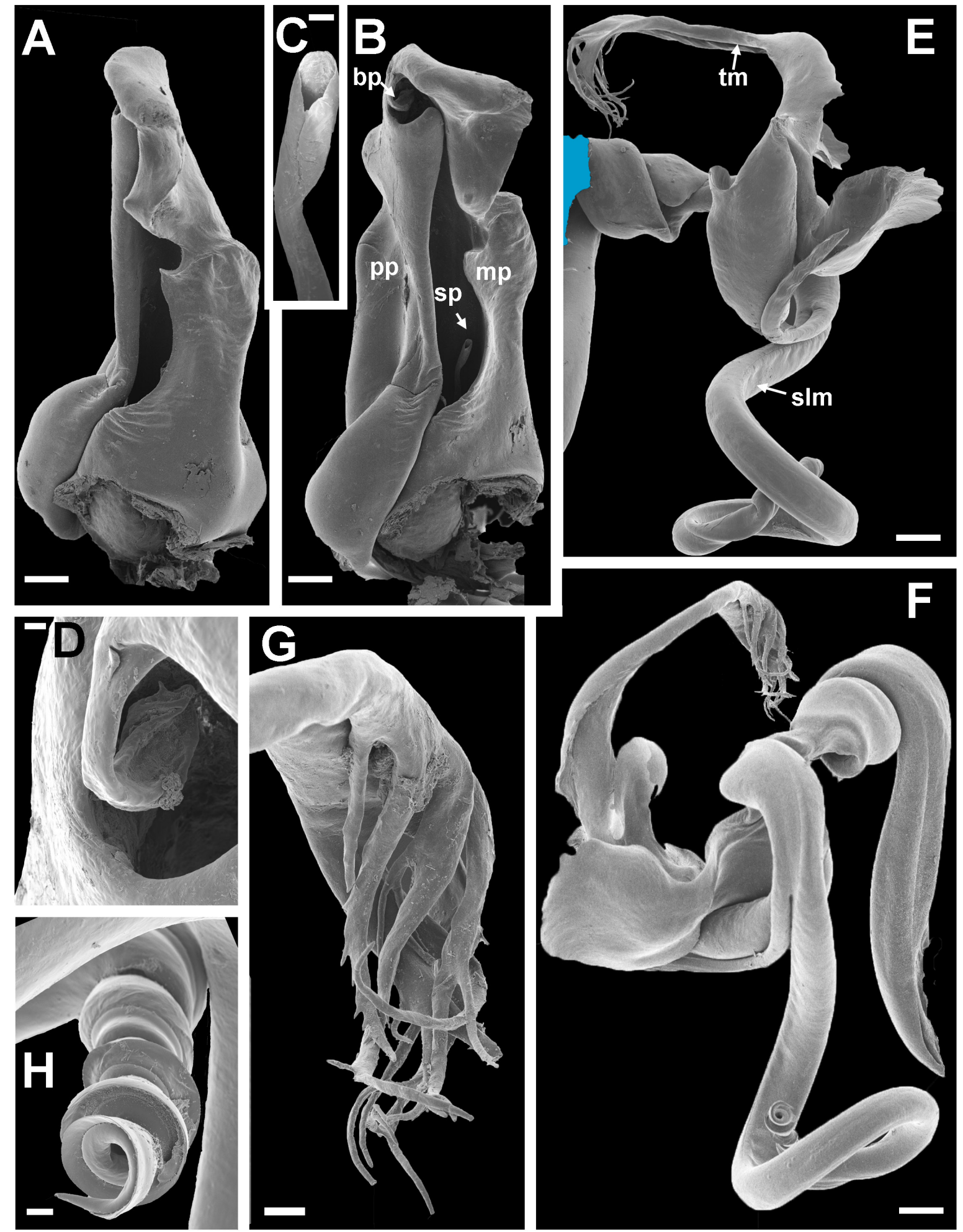

Fig. 5. Helicochetus dimidiatus (Peters, 1855), ภ̄, from Udzungwa Mts. Left gonopod. A-D. Coxa. A. Mesal view. B. Anterior view. C. Prostatic stylet. D. Apical basad process. E-H. Telopodite. E. Anterior view (the area marked with blue is covered by the mounting tape). F. Posterior view. G. Tip of telomere. H. Tip of solenomere. Abbreviations: $b p=$ apical basad process of coxa; $m p=$ metaplica; $p p=$ proplica; $s l m=$ solenomere; $s p=$ prostatic stylet; $t m=$ telomere. Scale bars: A-B, E-F $=0.2 \mathrm{~mm}$; $\mathrm{C}-\mathrm{D}, \mathrm{H}=0.02 \mathrm{~mm} ; \mathrm{G}=0.05 \mathrm{~mm}$. 
Female

Unknown.

\section{Distribution and habitat}

Known from several localities in Mozambique and Tanzania (Enghoff et al. 2016).

Verhoeff (1901) quoted a report on H. dimidiatus (as Odontopye attemsi Verhoeff, 1901) from the small island of Kwale (off the southern Tanzanian coast) where this species appeared in very large numbers, destroyed the islander's crops and forced them to move their agricultural activities to the mainland.

Helicochetus dimidiatus is sometimes kept in terraria, see, e.g., www.diplopoda.de/html/species/ hdimidiatus/_helico.php (accessed 19 Apr. 2007).

\section{Remarks}

The prostatic stylet ("stylet prostatique" sensu Brolemann 1920) is rarely seen, but seems to be a general feature of odontopygid and spirostreptid gonopods (Brölemann 1917; Brolemann 1920; Kraus 1966). This structure has been regarded as homologous with the cannula of Polydesmida and the flagella of many Julida, Cambalidea and Chordeumatida, in which case it would constitute a synapomorphy of subterclass Eugnatha sensu Enghoff et al. (2015); see discussions by Brolemann (1932), Demange (1967) and Enghoff (1984).

\section{Helicochetus mutaba Kraus, 1960}

Figs 4C-F, 6

Helicochetus mutaba Kraus, 1960: 40.

\section{Diagnosis}

Resembles H. digititarsus Kraus, 1957, H. gregorii (Pocock, 1896) and H. monodon Kraus, 1960 in the combination of a broad, shovel-like process ("Tibialdorn") at the level of the post-torsal narrowing; absence of ventral pads on male tibiae; presence of a basal lamella ("Grundblatt") on the telomere; tip of telomere not drawn out into long process, with several short to moderately long spine-like outgrowths from the margin. Differs from these species in the shape of the basal lamella: slender, pointed and curved (with a few denticles on the concave margin in the new specimens).

Material studied (total: $2 \widehat{\partial}$ )

TANZANIA: 1 §, KMH 2097, Nyumbenito Mt, forest near Udekwa, Uzungwa Mountains, 2000-3000 m a.s.l., date?, W.A. Rodgers leg. (VMNH); $1 \hat{\jmath}$, Iringa Region and District, Mazombo, $20 \mathrm{~km}$ NE of Iringa, 1700 m a.s.1., Jan. 1984, Jan Kielland leg. (ZMUC).

\section{Description}

Male

Based on studied specimens. Details from original description (Kraus 1960) in parentheses. Both of the new specimens are strongly fragmented and completely faded.

Size. Diameter 4.1-4.7 mm (4.0 mm), specimen from Mazombo with ca 64 podous rings, no apodous rings in front of telson, specimen from Nyumbenito Mt probably incomplete (48 podous rings present, no apodous rings in front of telson).

HEAD. Without peculiarities. Five supralabral setae (6). 
Collum. With two complete furrows on each side, none of them marginal (two distinct furrows, marginal furrow less distinct).

BODY RINGS. Almost perfect cylinders, not vaulted; suture straight; ozopores starting from ring 6, placed ca $1 / 3$ of metazonite length between suture and limbus. Ca 14 metazonital striae, reaching almost up to ozopore (10-11 striae, not at all reaching ozopore level). Surface microsculpture (Fig. 4D, F), see Remarks for genus.

ANAL VALVES. Dorsally drawn out into pointed triangular process, ventrally with small protruding knob; mesal margin raised, setiferous tubercles not detectable.

Limbus (Fig. 4C, E). See Remarks for genus.

MALE LEGS. With postfemoral ventral pads from first post-gonopodal leg-pair 3-5 until ca midbody.

Gonopod coxa (Fig. 6A-B). Lateral margin convex in basal half. Proplica $(p p)$ simple, with straight mesal margin, ending in small proplical lobe $(p p l)$. Metaplica $(m p)$ higher than proplica, apically regularly rounded, subapically with low mesal flange $(\mathrm{mmf})$, mesal margin of flange shallowly concave; distal, basad process $(b p)$ slender.

Gonopod telopodite (Fig. 6C-G). Basomere including torsotope without spines, arculus $90^{\circ}$. A large, shovel-like flange ( $s h l$ ) ("Tibialdorn") present at level of post-torsal narrowing (Fig. 6F). A long, slender, curved spine $(p s)$ at base of solenomere (Fig. 6E-F). Solenomere $(s l m)$ slender, round in transverse section, as long as telomere ( $\mathrm{tm}$ ), apically wound up in tight, corkscrew-like spiral; spiraled part basally delimited by tight, knob-like turn ( $k n)$ ("knotige Drehung") of solenomere shaft (Fig. 6G). Telomere basically a moderately narrow band curved in almost complete circle; with a curved, pointed basal lamella (btl) ("Grundblatt") pointing into main telomere curvature and with 1-2 small denticles on concave side (Fig. 6C, E) (no denticles); tip of telomere on specimen from Mazombo with several long, thin, spinelike processes from margin (Fig. 6D), in specimen from Nyumbenito Mt more shallowly serrate.

\section{Female}

Unknown.

\section{Distribution}

Hitherto known only from the type locality, Mutaba in the vicinity of Kirungu (= Baudoinville), in the Democratic Republic of the Congo. The two records from Tanzania, Nyumbenito Mt in the Udzungwa Range and Mazombo $\mathrm{N}$ of the Udzungwas, thus represent a considerable range extension. See, however, Remarks below.

\section{Remarks}

Helicochetus mutaba belongs to a group of very similar nominal species characterized by the following combination of key characters: a shovel-like lamella ("Tibialdorn") at the level of the post-torsal narrowing; no ventral pads on male tibiae; telomere with a basal lamella ("Grundblatt"); tip of telomere not drawn out into a long process, with several short to moderately long, spine-like outgrowths from the margin. This group consists of $H$. digititarsus Kraus, 1957 (Democratic Republic of the Congo), H. gregorii (Pocock, 1896) (Kenya), H. monodon (Kraus, 1960) (Zambia) and H. mutaba (Democratic Republic of the Congo, Tanzania). Table 2 shows the differences between these four species. The outline of the basal lamella of the telomere differs between the species, but it is not unlikely that future collections will bridge the small morphological gaps and that some or all of the four species will have to be synonymized. 

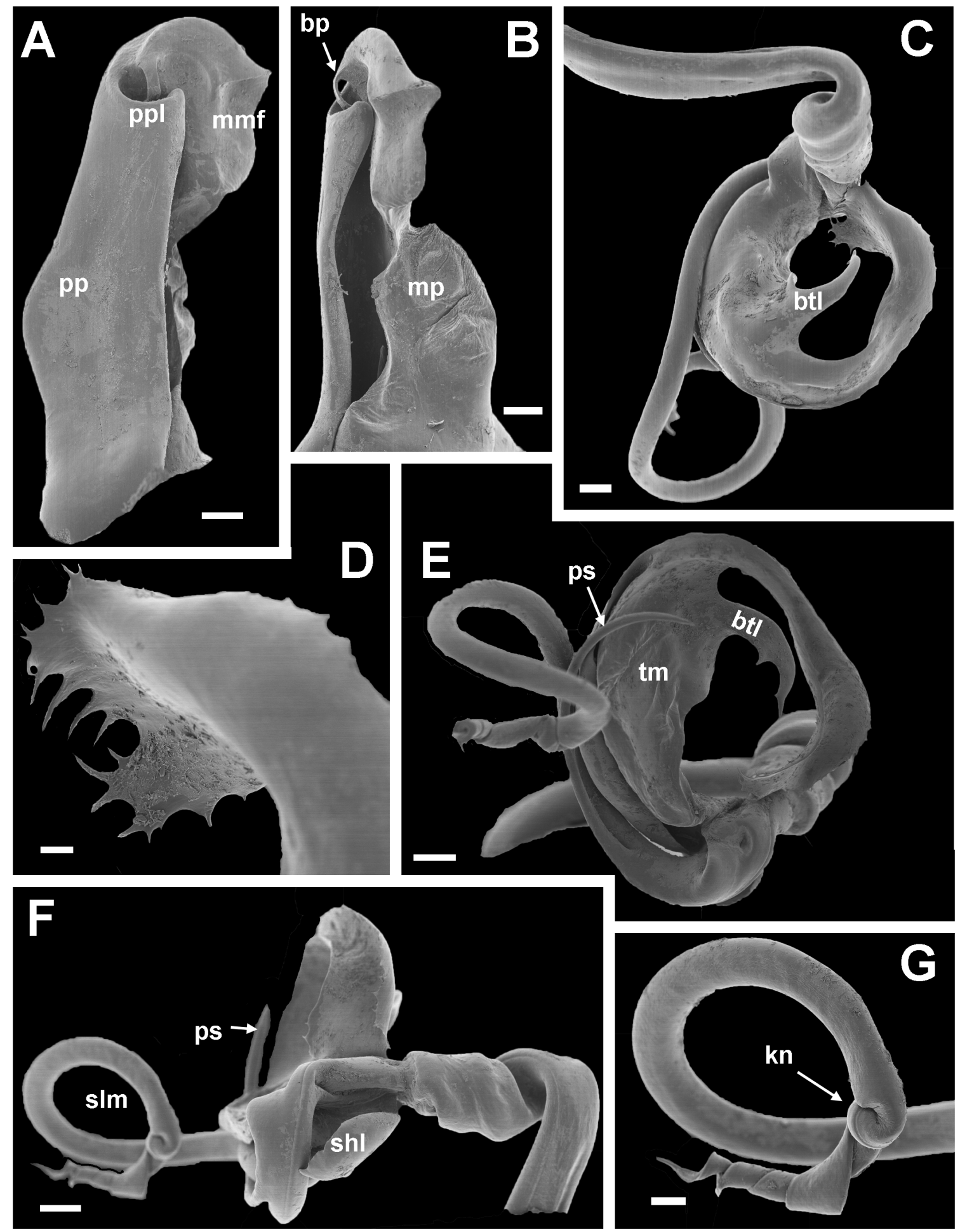

Fig. 6. Helicochetus mutaba Kraus, 1960, đ̃, from Mazombo. Left gonopod. A-B. Coxa. A. Anterior view. B. Mesal view. C-G. Telopodite. C. Anterior-lateral view. D. Detail of C (tip of telomere). E. Mesal-posterior view. F. Anterior-ventral view. G. Detail of F (tip of solenomere). Abbreviations: $b p=$ apical basad process of coxa; $b t l=$ basal lamella of telomere; $k n=$ knob-like turn of solenomere; $m m f=$ mesal metaplical flange; $m p=$ metaplica; $p p=$ proplica; $p p l=$ proplical lobe; $p s=$ proximal solenomeral spine; $s h l=$ shovel-like flange; $s l m=$ solenomere; $t m=$ telomere. Scale bars: A-C, E-F = $0.2 \mathrm{~mm} ; \mathrm{D}=0.05 \mathrm{~mm} ; \mathrm{G}=0.1 \mathrm{~mm}$. 
ENGHOFF H., Odontopygid millipedes from the Udzungwa Mts

Table 2. Comparison of four species of Helicochetus Attems, 1909.

\begin{tabular}{|c|c|c|c|c|c|}
\hline & $\begin{array}{l}\text { H. } \text { mutaba } \\
\text { Tanzania }\end{array}$ & $\begin{array}{l}\text { H. mutaba } \\
\text { D.R. of the Congo } \\
\text { (from Kraus 1960) }\end{array}$ & $\begin{array}{c}\text { H. digititarsus } \\
\text { (from Kraus 1960) }\end{array}$ & $\begin{array}{c}\text { H. gregorii } \\
\text { (from Pocock 1896 } \\
\text { and Kraus 1960) }\end{array}$ & $\begin{array}{c}\text { H. monodon } \\
\text { (from Kraus 1960) }\end{array}$ \\
\hline No. of body rings & ca 64 & $?$ & 60 & $71-72$ & 64 \\
\hline Body diameter $(\widehat{\jmath})$ & $4.1-4.7 \mathrm{~mm}$ & 4.0 & 3.7 & $?$ & 3.5 \\
\hline $\begin{array}{c}\text { Distal, basad } \\
\text { process }(b p) \text { on } \\
\text { coxa }\end{array}$ & long & long & long & short & long \\
\hline $\begin{array}{l}\text { Mesal margin of } \\
\text { distal part of coxa }\end{array}$ & $\begin{array}{l}\text { very shallowly } \\
\text { concave }\end{array}$ & shallowly concave & with a deep sinus & shallowly concave & shallowly concave \\
\hline $\begin{array}{l}\text { Basal lamella of } \\
\text { telomere }(b t l)\end{array}$ & $\begin{array}{l}\text { slender, pointed, } \\
\text { curved, with a } \\
\text { few denticles on } \\
\text { concave margin }\end{array}$ & $\begin{array}{l}\text { slender, pointed, } \\
\text { curved, smooth }\end{array}$ & $\begin{array}{l}\text { very slender, } \\
\text { pointed, smooth }\end{array}$ & $\begin{array}{l}\text { broad, } \\
\text { subrectangular, } \\
\text { smooth }\end{array}$ & $\begin{array}{l}\text { slender, margin in } \\
\text { part serrate }\end{array}$ \\
\hline Tip of telomere & $\begin{array}{c}\text { margin with } \\
\text { short or long, } \\
\text { slender denticles }\end{array}$ & $\begin{array}{l}\text { margin with short } \\
\text { denticles }\end{array}$ & $\begin{array}{l}\text { margin with short } \\
\text { denticles }\end{array}$ & $\begin{array}{l}\text { with many short } \\
\text { and long denticles, } \\
\text { apparently not only } \\
\text { on margin }\end{array}$ & $\begin{array}{l}\text { margin with short } \\
\text { denticles }\end{array}$ \\
\hline $\begin{array}{l}\text { Solenomere with a } \\
\text { 'knot' }(\mathrm{kn}) \text { at base } \\
\text { of terminal spiral }\end{array}$ & yes & yes & yes & no & yes \\
\hline $\begin{array}{l}\text { Terminal spiral of } \\
\text { solenomere with } \\
\text { an accessory spine }\end{array}$ & yes & yes & yes & no & yes \\
\hline
\end{tabular}

Enghoff et al. (2016) recorded H. digititarsus from two Tanzanian localities: 1) Mara Region, Serengeti District, Seronera, Serengeti National Park; 2) Tabora Region, Nzega District, Nzega City. In light of the above discussion, it cannot be excluded that these specimens are conspecific with the one recorded here as H. mutaba.

The vial containing the male from Mazombo also contained a microvial with a mite which was presumably collected in association with the millipede. The mite was infested with numerous thalli of the fungus Rickia sp. (Ascomycota, Laboulbeniales). Several species of mites are known to be closely associated with millipedes (Farfan \& Klompen 2012), and several species of Rickia Cavara are known to use mites as their host (Tavares 1985; Seeman \& Nahrung 2000), but this seems to be the first known instance of a Rickia-mite-millipede association.

Genus Hoffmanides Kraus, 1968

Hoffmanides Kraus, 1966: 134.

\section{Type species}

Spinotarsus dissutus Hoffman, 1963, by original designation and monotypy.

\section{Remarks}

This genus, remarkable for is widely open gonopod coxa, was erected by Kraus for a species originally placed in the large, mainly southern African genus Spinotarsus Attems, 1909. By doing so, Kraus deprived Tanzania of the genus Spinotarsus, an action neutralized by the description below of a new Tanzanian species of Spinotarsus. 


\section{Hoffmanides dissutus (Hoffman, 1963)}

Figs $7-8$

Spinotarsus dissutus Hoffman, 1963: 1.

Hoffmanides dissutus - Kraus (1966): 135.

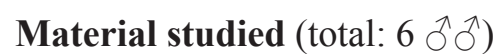

TANZANIA: $6 \hat{\jmath}$, , Iringa-Morogoro Regions, Udzungwa National Park, 350 m a.s.1., 8 Dec. 1995,

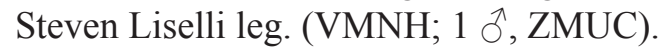

\section{Description}

\section{Male}

Based on studied specimens. Details from previous descriptions (Hoffman 1963; Kraus 1966) in parentheses. Considering that two detailed descriptions of $H$. dissutus are thus available, and that the studied specimens agree completely with both of them, only a few details are highlighted here.

SizE. Diameter 3.5-3.9 mm (3.7 mm); 61-64 podous rings, no apodous rings in front of telson ("56 Segmente").

HEAD. Without peculiarities. Five supralabral setae (6).

Colour. After 22 years in alcohol, overall yellowish (Fig. 7); prozonites from ozopore level up to ca $2 / 3$ of distance to midline blackish; also a thin blackish midline, i.e., dorsum with two paramedian yellow bands.

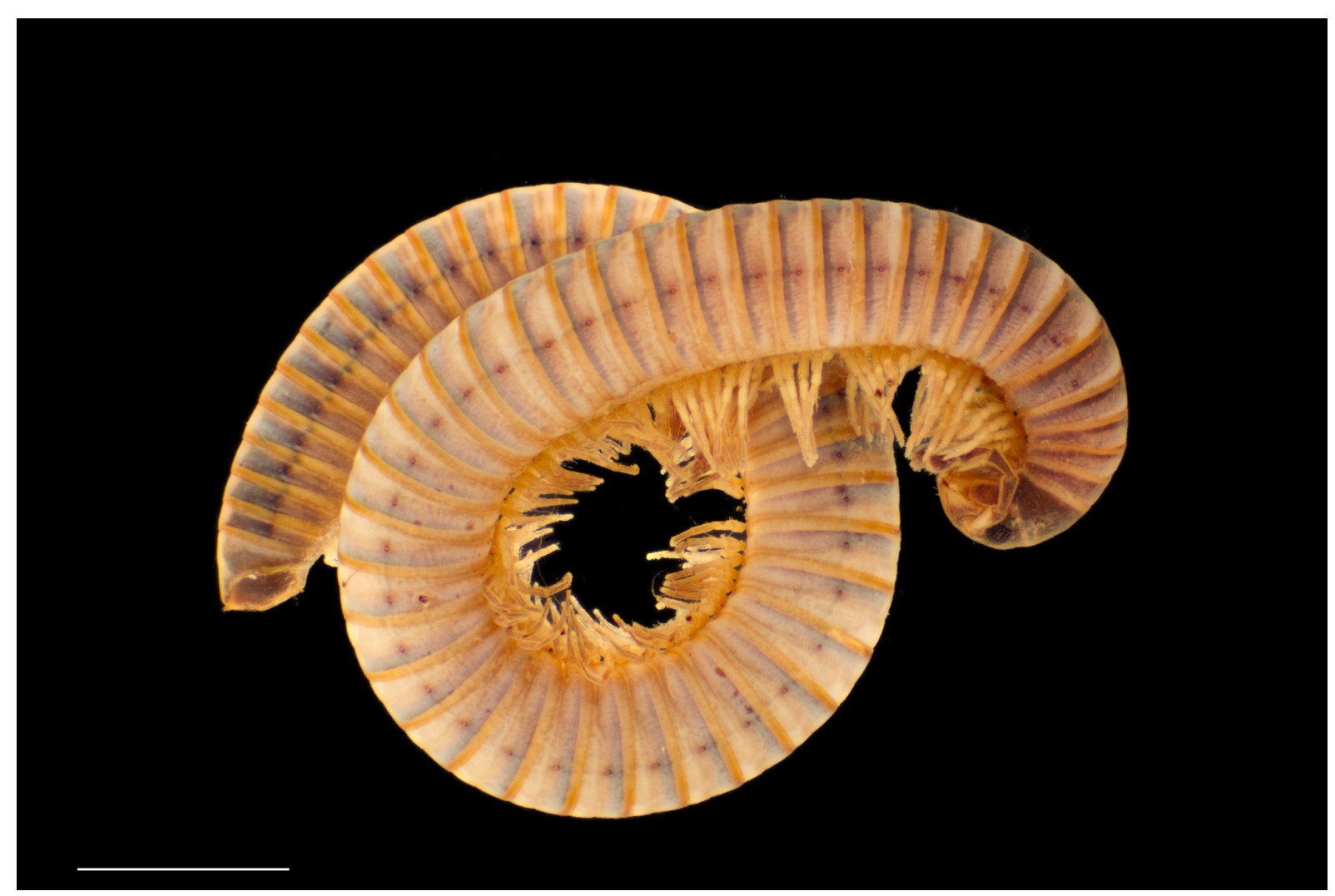

Fig. 7. Hoffmanides dissutus (Hoffman, 1963), ô, from Udzungwa Mts National Park. Photograph by A. Illum. Scale bar $=5 \mathrm{~mm}$. 
Anal valves (Fig. 8A-B). Dorsally drawn out into pointed, triangular, spine-like process, ventrally with small protruding knob; mesal margin raised, setiferous tubercles, especially middle one $(s t u)$ on pronounced "ravelins".
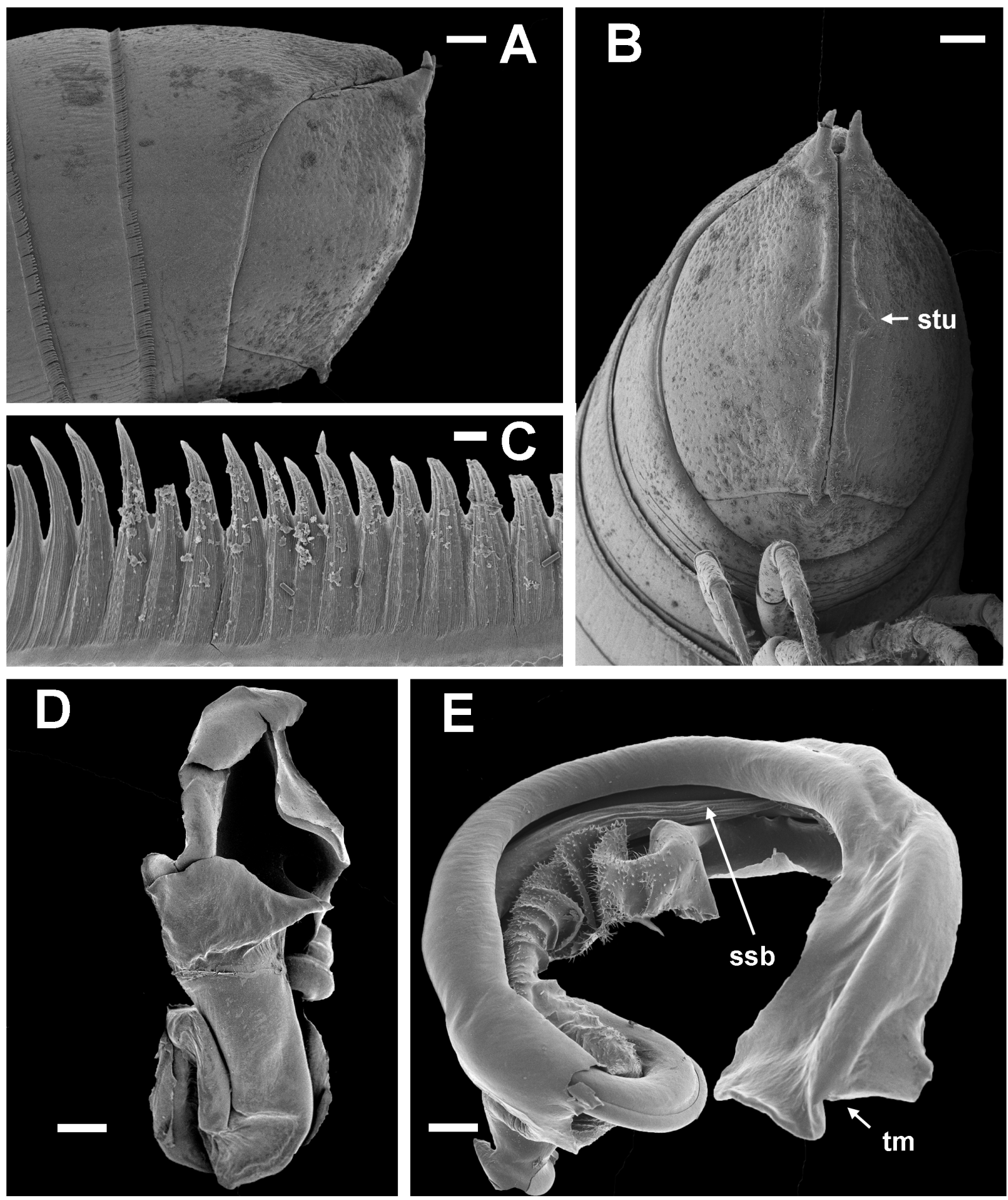

Fig. 8. Hoffmanides dissutus (Hoffman, 1963), ô, from Udzungwa Mts National Park. A-B. Telson. A. Lateral view. B. Posterior view. C. Limbus. D. Gonopod coxa, anterior view. E. Gonopod telopodite, posterior-mesal view. Abbreviations: $s s b=$ spine-like side branch of solenomere, nested in cavity of telomere; $s t u=$ middle setiferous tubercle on "ravelin"; $t m=$ tip of telomere. Scale bars: A-B, $\mathrm{D}=0.2 \mathrm{~mm} ; \mathrm{C}=0.001 \mathrm{~mm} ; \mathrm{E}=0.1 \mathrm{~mm}$. 
Limbus (Fig. 8C). With long, spine-like lobes.

GoNOPOD COXA (Fig. 8D). As illustrated by Hoffman (1963) and Kraus (1966).

Gonopod telopodite (Fig. 8E). As illustrated by Kraus (1966). In some specimens the solenomere is hidden within the telomere (Fig. 8E), but in others the solenomere has come free (due to preservation?), and the long, spine-like branch ( $s s b)$ arising from it, overlooked by Hoffman (1963) but illustrated by Kraus (1966: fig. 358), is obvious.

\section{Female}

Unknown.

\section{Distribution}

Helicochetus dissutus was described from "Morogoro" (Hoffman 1963); this does not necessarily refer to the city of Morogoro, ca $150 \mathrm{~km} \mathrm{NE}$ of Udzungwa National Park, but possibly to anywhere in the Morogoro Region. Enghoff et al. (2016) also recorded the species from the Morogoro Region, Uluguru Mts, Morningside.

Genus Spinotarsus Attems, 1909

Spinotarsus Attems, 1909b: 46.

\section{Type species}

Spinotarsus xanthonotus Attems, 1909.

\section{Other included species}

Almost one hundred; see Kraus $(1960,1966)$.

\section{Remarks}

The vast majority of species of Spinotarsus occur in southern Africa; only two, viz, S. serrulatus Kraus, 1958 and S. terrestris (Attems, 1935), are from the Democratic Republic of the Congo. Two species described from other parts of the Afrotropical region have subsequently been transferred to other genera: S. caboverdus Pierrard, 1987 (Cape Verde Islands) was transferred to the genus Bandeirenica Kraus, 1960 by Hoffman (2000); S. dissutus Hoffman, 1963 (Tanzania), was made type of the genus Hoffmanides by Kraus (1966), see above. The new species described below is thus the first true Spinotarsus from Tanzania.

Spinotarsus fortehamatus sp. nov. urn:1sid:zoobank.org:act:B9ACE322-7B35-4879-9DC4-B5F08E666121

Fig. 9

\section{Diagnosis}

A species of Spinotarsus characterized by the very large, regularly curving lateral metaplical spine, in combination with the presence of a spine at the base of the solenomerite and a row of denticles on the terminal part of the telomere.

\section{Etymology}

The name is a composite Latin adjective, meaning "with a strong hook" and referring to the strong lateral, hook-shaped spine of the gonopod coxa. 
Material studied (total: 1 ふ)

\section{Holotype}

TANZANIA: $\widehat{\lambda}$, Morogoro Region, Udzungwa Mountains National Park, Sanje Kati camp and plot, 0745'47.6" S, 3653'10.4" E, 850 m a.s.l., 7 Feb. 2014, J. Malumbres-Olarte leg. (ZMUC).

\section{Description}

\section{Male}

SizE. Length ca $6 \mathrm{~cm}$, diameter $5.0 \mathrm{~mm}, 59$ podous rings, no apodous rings in front of telson.

CoLour. Apparently quite well-preserved after 3 years in alcohol: head below antennae yellowish; head above antennae blackish, parietal and interocular furrows contrastingly yellow; antennae brown, collum blackish with lighter margins; body rings light grey, metazona with black sputtering, posterior $1 / 3$ of metazona amber; a yellow dorsal longitudinal stripe on posterior $1 / 4$ of body; legs yellow; preanal ring grey, dorsally yellow; anal valves blackish with lighter margin; subanal scale yellow.

HEAD. Parietal and interocular furrows present; 7 supralabral setae. Antennae reaching to ring 6 when folded back. Eyes reaching to median tangent to antennal socket, each with nine rows of ommatidia, 7 horizontal rows, and a total of ca 38 ommatidia each.

CoLLum. Lateral lobes subrectangular, each with two furrows.

BODY RINGS. Unvaulted; metazona and posterior part of prosoma with numerous short very fine longitudinal furrows; ozopores ca $1 / 3$ of metazona length behind straight suture.

Ozopores. Missing from rings 31 (left side), 47 (both sides), 56 (right), 58 (left) and 59 (both).

AnAL VAlves. Each with a stout dorsal spine and a tiny ventral knob-like spine; mesal margin slightly raised, setiferous tubercles indistinct, not on ravelins.

LimBus (Fig. 9G). With long (more than twice as long as broad), pointed lobes.

GonOpOD COXA (Fig. 9F). Slightly more than twice as long as broad. Proplica ending in small proplical lobe $(p p l)$. Metaplica longer than proplica, apically forming a "cucullus" ( $c u)$. Mesal margin of metaplica with a curved lamellar process ( $\mathrm{mlp}$ ) just distal to exit point of telopodite ("arculus"). Metaplica laterally with a very large spine ( $m s p$ ) curving distad in a latero-posterior plane. Proplical lobe, lateral metaplical spine and a stripe parallel to lateral metaplical margin from spine to tip of cucullus black (not visible on SEM image).

Gonopod telopodite (Fig. 9A-E). Arculus 90 . A very long post-torsal spine (pts) making almost $1 \frac{1}{2}$ turns around torsotope $(t t)$ (Fig. 9C-D). Solenomere $(s / m)$ as long as telomere, thin, simple, without outgrowths, apically with oblique-longitudinal fluting. A long spine ( $p s$ ) originating at base of solenomere and projecting at right angles to it (Fig. 9A). Telomere $(\mathrm{tm})$ curving in an almost complete circle, basally with large spinose lamella (bla) projecting into space delimited by telomere curvature, followed by two smooth lamellae (ell, el2) projecting from outside of curvature (Fig. 9A); distal part of telomere slender, longitudinally folded, one margin with a series of black denticles $(t d$, colour not visible on SEM image; Fig. 9D).

\section{Female}

Unknown. 

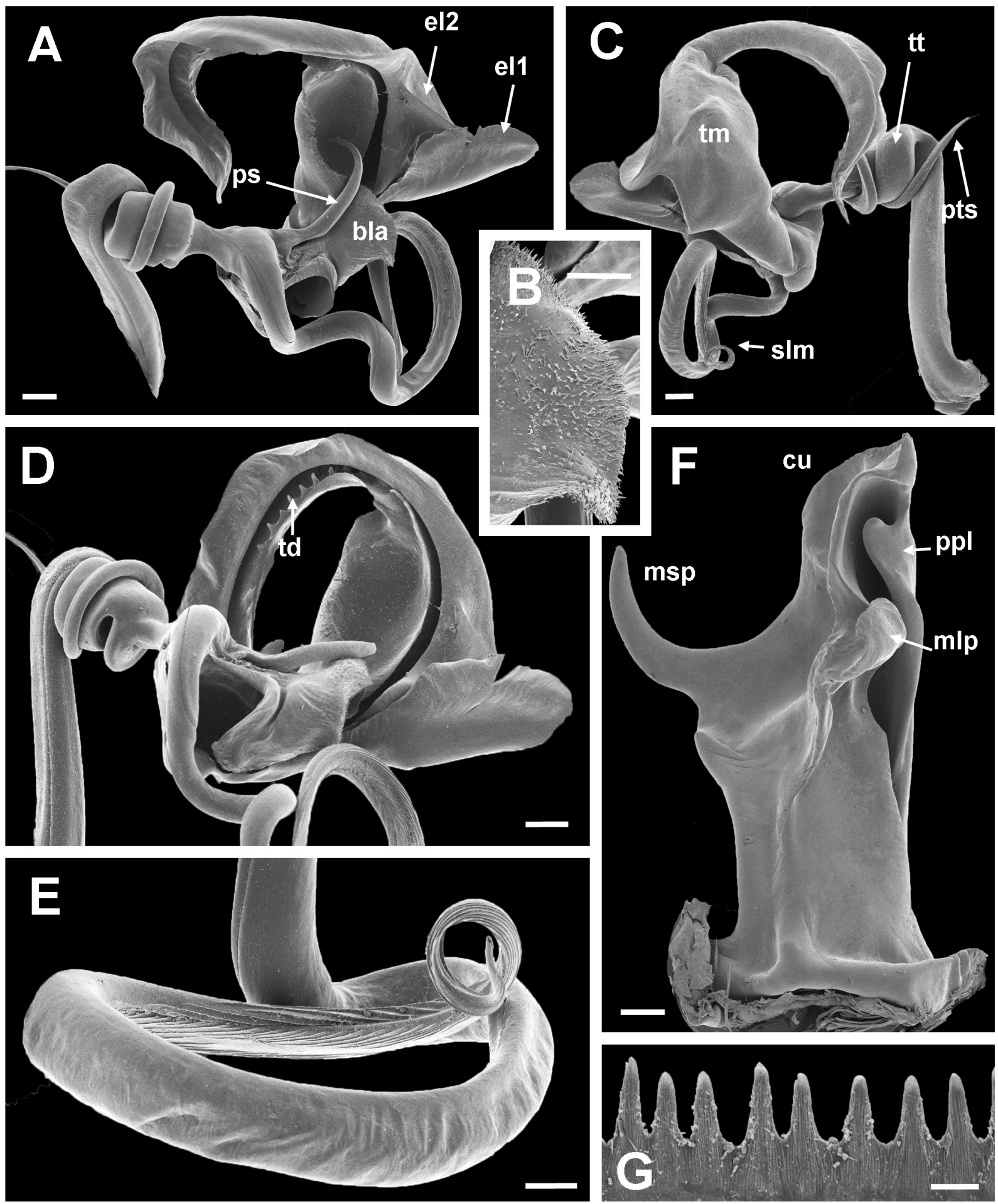

Fig. 9. Spinotarsus fortehamatus sp. nov., holotype. A-E. Right gonopod telopodite. A. Posterior view. B. Basal lamella of telomere, enlarged. C. Anterior view. D. Posterior-mesal view. E. Distal part of solenomere. F. Right gonopod coxa, posterior and slightly mesal view. G. Limbus. Abbreviations: $b l a=$ basal lamella of telomere; $c u=$ cucullus; $e l l, e l 2=$ smooth telomeral lamellae; $m l p=$ metaplical lamellar process; $m s p=$ metaplical spine-like process; $p p l=$ proplical lobe; $p s=$ proximal solenomeral spine; $p t s=$ post-torsal spine; $s t m=$ solenomere; $t d=$ telomeral denticles; $t m=$ telomere; $t t=$ torsotope. Scale bars: A, C-D, F = $0.2 \mathrm{~mm} ; \mathrm{B}, \mathrm{E}=0.1 \mathrm{~mm} ; \mathrm{G}=0.01 \mathrm{~mm}$. 


\section{Remarks}

The basal spinose lamella of the telomere (bla) is a key character for Spinotarsus (the name actually refers to the lamella - the telomere was formerly referred to as the tarsus). Many species of Spinotarsus possess an additional apomorphy, namely a darkly sclerotized ridge on the posterior surface of the telomere, but such a ridge is absent in $S$. fortehamatus sp. nov. In the most recent key to species of Spinotarsus (Kraus 1966: 110-113), the new species keys out without problems to couplet 60, as follows (couplet texts translated from German and adapted to current terminology, characters of $S$. fortehamatus sp. nov. in bold): couplet 1: Gonopodal metaplica with one or several dark sclerotized lateral spines which stand clearly out in strict oral view $\rightarrow$ couplet 38: One or more spine(s) ("Postfemoraldorn") at base of solenomere present $\rightarrow$ couplet 59: One spine at base of solenomere $\rightarrow$ couplet 60 . "Couplet" 60 is, however, deficient in the key, which can be seen by comparison with the older key by Kraus (1960: 122 , "couplet" 42). The "couplet" in question is actually a "triplet", but the third option is lacking in the 1966 key. In translation, "triplet" 60 in Kraus (1966) should run:

60. Metaplica distally coarsely serrate

denticulatus

- Metaplica distally ending in a slender, spine-like process with a blackened tip; this process inserting apico-mesally

- Tip of metaplica different

Continuing in couplet 65, the new species fulfils the second alternative: Lateral metaplical spine directed \pm apicad $\rightarrow$ couplet 68 : Metaplica apically without a process or just with a delicate hyaline, spoonshaped appendage $\rightarrow$ couplet 81: Terminal lamella of telomere with spiny margin and 1-2 longitudinal rows of denticles on the internal surface $(\rightarrow$ couplet 82 ) vs Terminal lamella of telomere completely smooth, internal surface of telomere without obvious spine rows ( $\rightarrow$ couplet 84 ). The new species has a smooth margin of the terminal part of the telomere, but it also has a very obvious row of spines on the internal surface of the telomere. It thus fits one criterium of each alternative. In addition to its unique combination of key characters, it also differs from congeners in the shape of the lateral metaplical spine: none of the almost one hundred described species of Spinotarsus have an equally large, equally smoothly curved lateral metaplical spine. Those which come closest in this character, i.e., S. demotus Kraus, 1966 (Angola), S. kruegeri Kraus, 1966 (South Africa), S. lanceolatus Kraus, 1966 (Zimbabwe) and S. pusillus Kraus, 1966 (South Africa), differ clearly in other characters.

The lack of ozopores on one or both sides of certain body rings is a highly unusual trait. In juliformian millipedes, ozopores are normally present in an uninterrupted series usually starting on body ring 6, rarely on ring 5, exceptionally on ring 3 , and continuing to include the last podous ring. Up to now, the only exception to this rule is constituted by two species of the family Mongoliulidae, in which ozoporeless body rings occur in a regular pattern along the body (Enghoff et al. 2017).

\section{Discussion}

\section{The Odontopygidae of the Udzungwa Mountains}

Thirty-nine species of Odontopygidae (Table 3) are now known from the Udzungwa Mts as a result of the series of studies entitled "A mountain of millipedes" (Enghoff 2014, 2016a, 2016b, 2016c; Enghoff \& Frederiksen 2015; this paper). Previously, just one species (Chaleponcus dabagaensis Kraus, 1958) was known. Based on the examination of a huge collection of millipedes from the Udzungwas, Odontopygidae is clearly the most species-rich millipede family in these mountains. Paradoxosomatidae are also represented by many species, whereas such families as Spirostreptidae, Oxydesmidae, Gomphodesmidae, Chelodesmidae, several families of "micropolydesmoids" and Stemmiulidae seem to have no more than one or two handfuls of species each. 
Table 3. Species of Odontopygidae known from the Udzungwa Mts. Endemic $=$ endemic to the Udzungwa Mts.

\begin{tabular}{|c|c|c|}
\hline Species & Distribution & $\begin{array}{l}\text { Altitudinal range in the } \\
\text { Udzungwa Mts ( } \mathrm{m} \text { a.s.l.) }\end{array}$ \\
\hline 1. Aquattuor longipala Enghoff, 2015 & endemic & $1390-1410$ \\
\hline 2. A. major Enghoff, 2015 & endemic & $1650-1850$ \\
\hline 3. A. stereosathe Enghoff, 2015 & endemic & $900-1500$ \\
\hline 4. A. submajor Enghoff, 2015 & endemic & $1000-1250$ \\
\hline 5. A udzungwensis Enghoff, 2015 & endemic & $750-1410$ \\
\hline 6. Casuariverpa scarpa Enghoff, 2016 & endemic & 1050 \\
\hline 7. Chaleponcus basiliscus Enghoff, 2014 & endemic & $?$ \\
\hline 8. C. circumvallatus Enghoff, 2014 & endemic & $1390-1650$ \\
\hline 9. C. dabagaensis Kraus, 1958 & endemic & $1700-1955$ \\
\hline 10. C. gracilior Enghoff, 2014 & endemic & $1500-2100$ \\
\hline 11. C. hamerae Enghoff, 2014 & endemic & $1600-1800$ \\
\hline 12. C. howelli Enghoff, 2014 & endemic & $1700-1900$ \\
\hline 13. C. ibis Enghoff, 2014 & endemic & $?$ \\
\hline 14. C. krai Enghoff, 2014 & endemic & $1900-2100$ \\
\hline 15. C. malleolus Enghoff, 2014 & endemic & 1904-1944 \\
\hline 16. C. mwabvui Enghoff, 2014 & endemic & $1800-1955$ \\
\hline 17. C. mwanihanensis Enghoff, 2014 & endemic & $1800-1850$ \\
\hline 18. C. nectarinia Enghoff, 2014 & endemic & $1930-1955$ \\
\hline 19. C. netus Enghoff, 2014 & endemic & $1390-1963$ \\
\hline 20. C. nikolajscharffi Enghoff, 2014 & endemic & $1400-1800$ \\
\hline 21. C. quasimodo Enghoff, 2014 & endemic & $1700-1900$ \\
\hline 22. C. scopus Enghoff, 2014 & endemic & $1700-1900$ \\
\hline 23. C. teres Enghoff, 2014 & endemic & $1930-1950$ \\
\hline 24. C. termini Enghoff, 2014 & endemic & $1800-1955$ \\
\hline 25. C. tintin Enghoff, 2014 & endemic & 2100 \\
\hline 26. C. vandenspiegeli Enghoff, 2014 & endemic & $1800-1900$ \\
\hline 27. C. vilici Enghoff, 2014 & endemic & $1908-1955$ \\
\hline 28. Damacornu transversum gen. et sp. nov. & endemic & 1400 \\
\hline 29. Geotypodon millemanus Enghoff, 2016 & endemic & $1145-1500$ \\
\hline 30. G. submontanus Enghoff, 2016 & endemic & 1145 \\
\hline 31. G. papei sp. nov. & endemic & $339-650$ \\
\hline 32. Helicochetus dimidiatus (Peters, 1855) & $\begin{array}{l}\text { Tanzania, widespread; } \\
\text { Mozambique (Enghoff } \text { et al. 2016) }\end{array}$ & 339 \\
\hline 33. H. mutaba Kraus, 1960 & Tanzania, D.R. of the Congo & $1700-3000$ \\
\hline 34. Hoffmanides dissutus (Hoffman, 1963) & Tanzania & 350 \\
\hline 35. Prionopetalum asperginis Enghoff, 2016 & endemic & $550-750$ \\
\hline 36. P. kraepelini (Attems, 1896) & $\begin{array}{l}\text { Tanzania, widespread } \\
\text { (Enghoff 2016b) }\end{array}$ & $300-339$ \\
\hline 37. Spinotarsus fortehamatus sp. nov. & endemic & 850 \\
\hline 38. Utiliverpa decapsulatrix Enghoff, 2016 & endemic & $?$ \\
\hline 39. Yia geminispina Enghoff, 2016 & endemic & 1100 \\
\hline
\end{tabular}


Out of the 39 odontopygid species, no less than 35 are known only from the Udzungwa Mts and should be regarded as Udzungwa endemics. No phylogenetic analyses are available for any Udzungwan odontopygid, but nevertheless some preliminary geographical patterns may be inferred (Fig. 10):

- The endemic Chaleponcus dabagaensis group seems to be most closely related to C. altirungwensis Enghoff, 2017 from Mt Rungwe, SW of the Udzungwas, see Enghoff (2017a, 2017b).

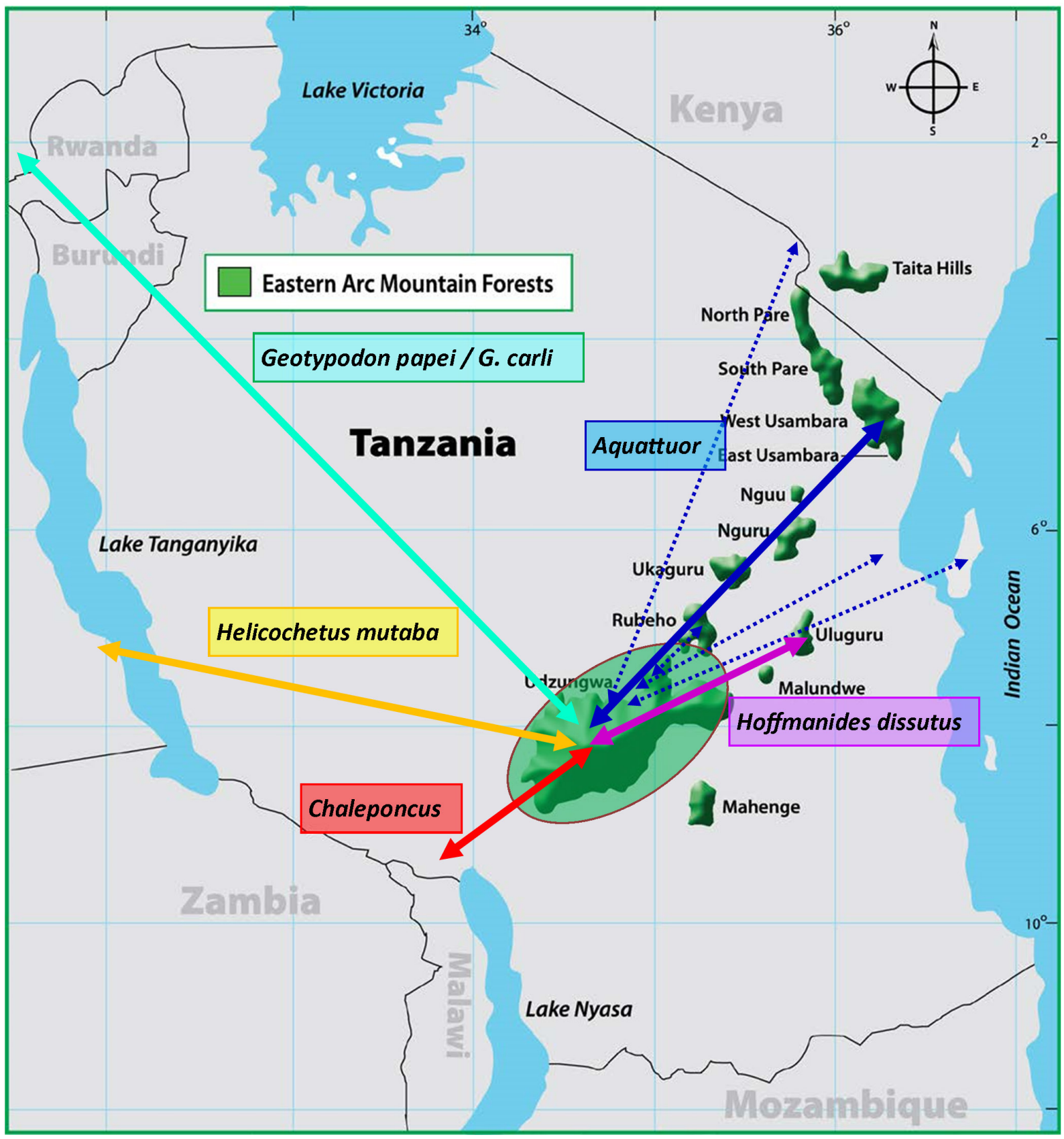

Fig. 10. Geographical relationships of the Odontopygidae of the Udzungwa Mts. See main text for explanation. No relationships are shown for the three endemic genera (Casuariverpa Enghoff, 2016, Utiliverpa Enghoff, 2016 and Yia Enghoff, 2016), nor for the Udzungwa species of the large genus Spinotarsus Attems, 1909, nor for the widespread species Helicochetus dimidiatus (Peters, 1855) and Prionopetalum kraepelini (Attems, 1896). Base map by permission of the Eastern Arc Mountains Conservation Endowment Fund. 
- The genus Aquattuor (five endemic species in the Udzungwas) has a further species endemic to the E Usambara Mts, and still one (or two?) species recorded from several sites in NE Tanzania, where they may have arrived by means of human transportation (Enghoff 2016b; Enghoff \& Frederiksen 2015).

- Hoffmanides dissutus (Hoffman, 1963) is also known from the Uluguru Mts.

- Geotypodon papei sp. nov. is very similar to and presumably closely related to G. carli Kraus, 1960 (Democratic Republic of the Congo).

- Helicochetus mutaba is also known from the eastern Democratic Republic of the Congo.

Odontopygid "tracks" thus connect the Udzungwa Mts with other mountain blocks in the (extended) Eastern Arc (Aquattuor, Chaleponcus and Hoffmanides dissutus, but surprisingly also with areas in the Democratic Republic of the Congo further west.

The altitudinal distribution of the odontopygids (Fig. 11) shows a striking pattern: the endemic species swarm constituted by the Chaleponcus dabagaensis group (Enghoff 2014) occupies high altitudes (species medians ranging from 1520 (C. circumvallatus Enghoff, 2014) to $2100 \mathrm{~m}$ a.s.l. (C. tintin Enghoff, 2014). Other endemic species occur at lower altitudes (medians: 400-1799 $\mathrm{m}$ a.s.1.), whereas three out of four non-endemic species all occur at low altitudes (medians: 300-399 m), as might be expected.

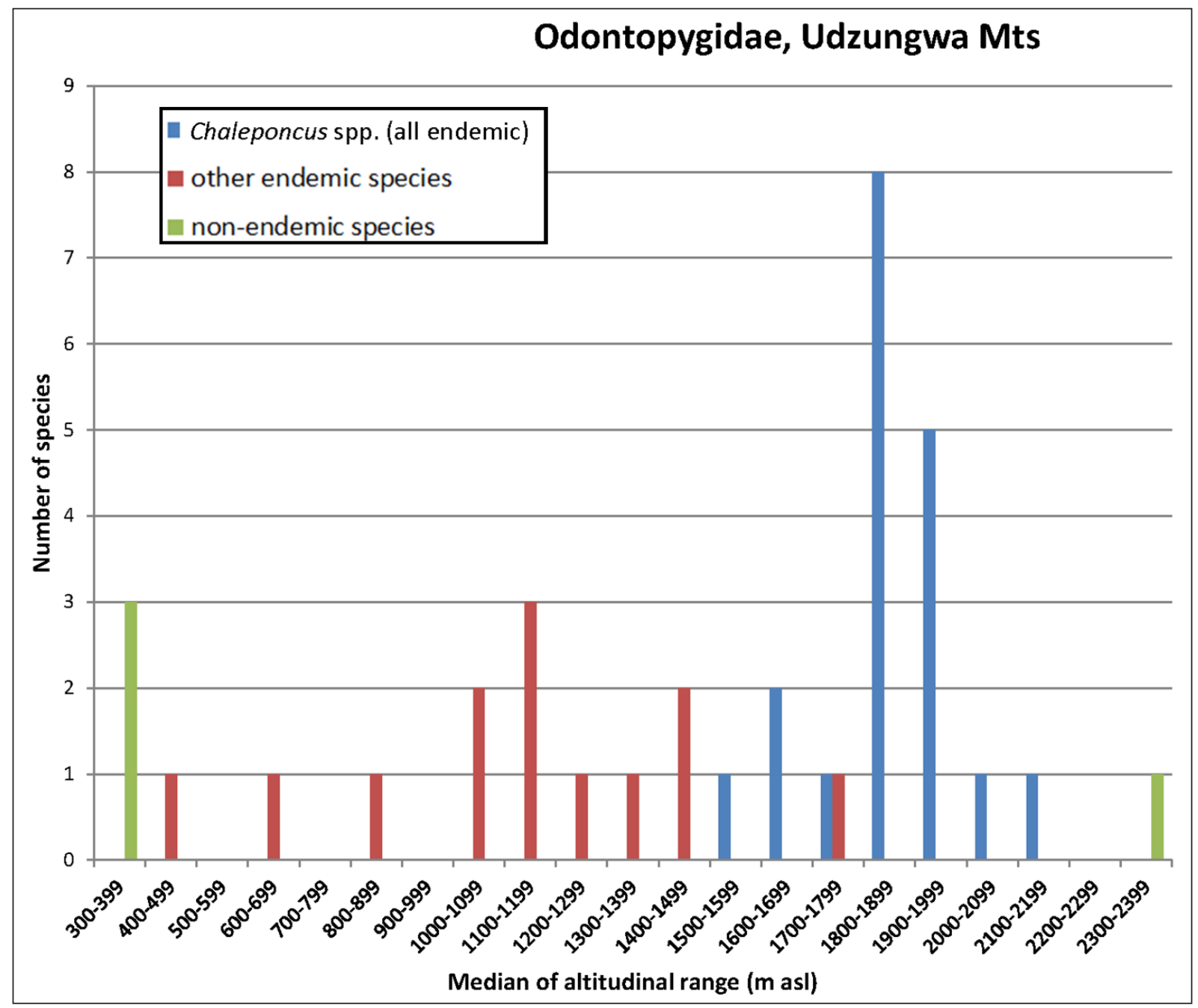

Fig. 11. Odontopygidae of the Udzungwa Mts, altitudinal distribution. Based on medians of the altitudinal ranges shown in Table 3. 
The striking exception is Helicochetus mutaba with a median occurrence altitude in the Udzungwas of $2350 \mathrm{~m}$ a.s.1. It seems highly unlikely that this species, described from the Democratic Republic of the Congo (the altitude of the type locality, Mutaba, is unknown, but the town of Kirungu in the territory of which Mutaba was stated to be situated, is at an altitude of $400 \mathrm{~m}$ a.s.1.), should occur naturally at 2000-3000 m a.s.l. in the Udzungwas (as well as at $1700 \mathrm{~m}$ a.s.l. at Mazombo), another hint that the current species-level taxonomy of Helicochetus is in need of further scrutiny.

\section{Acknowledgements}

Thanks are due to the Tanzanian authorities that granted permits for collecting in the Udzungwa Mountains, as well as to my colleagues at the Natural History Museum of Denmark for providing specimens, to Judith Winston and her colleagues at VMNH for access to a specimen in that museum, to Francis B.N. Sabuni, Eastern Arc Mountains Conservation Endowment Fund, for permission to use the base map for Fig. 10, to Hans Reip for help with literature access and to Anders Illum for photography.

\section{References}

Attems C. 1909a. Zur Systematik der Spirostreptoidea. Zoologischer Anzeiger 34 (5): 156-159. Available from https://biodiversitylibrary.org/page/30144159 [accessed 27 Nov. 2017].

Attems C. 1909b. Myriopoden. In: Schultze L. (ed.) Forschungsreise im westlichen und zentralen Südafrika ausgeführt in den Jahren 1903-1905. Denkschriften der Mathematisch-Naturwissenschaftlichen Classe der Kaiserlichen Akademie der Wissenschaften 14: 1-52.

Attems C. 1914. Afrikanische Spirostreptiden nebst Überblick über die Spirostreptiden orbis terrarum. Zoologica (Stuttgart) 25: 1-235.

Brölemann H.W. 1917. Le stylet prostatique des spirostreptes. Bulletin de la Société entomologique de France 1917: 151-152.

Brolemann H.W. 1920. Diplopoda. In: Voyage de Ch. Alluaud et R. Jeannel en Afrique Orientale: 19111912. Résultats scientifiques: 49-298.

Brolemann H.W. 1932. Le contraction tachygénétique des polydesmiens (myriapodes) et leurs affinités naturelles. Bulletin de la Société zoologique de France 57: 387-396.

Demange J.-M. 1967. Recherches sur la segmentation du tronc des chilopodes et des diplopodes chilognathes (myriapodes). Mémoires du Muséum national d'Histoire naturelle, Series A 44: 1-188.

Enghoff H. 1984. Phylogeny of millipedes - a cladistic analysis. Zeitschrift für zoologische Systematik und Evolutionsforschung 22: 8-26. https://doi.org/10.1111/j.1439-0469.1984.tb00559.x

Enghoff H. 2014. A mountain of millipedes I: An endemic species-group of the genus Chaleponcus Attems, 1914, from the Udzungwa Mountains, Tanzania (Diplopoda, Spirostreptida, Odontopygidae). European Journal of Taxonomy 100: 1-75. https://doi.org/10.5852/ejt.2014.100

Enghoff H. 2016a. A mountain of millipedes III: A new genus for three new species from the Udzungwa Mountains and surroundings, Tanzania, as well as several 'orphaned' species previously assigned to Odontopyge Brandt, 1841 (Diplopoda, Spirostreptida, Odontopygidae). European Journal of Taxonomy 177: 1-19. https://doi.org/10.5852/ejt.2016.177

Enghoff H. 2016b. A mountain of millipedes IV: Species of Prionopetalum Attems, 1909, from the Udzungwa Mountains, Tanzania. With notes on "P." fasciatum (Attems, 1896) and a revised species key (Diplopoda, Spirostreptida, Odontopygidae). European Journal of Taxonomy 215: 1-23.

https://doi.org/10.5852/ejt.2016.215 
Enghoff H. 2016c. A mountain of millipedes V: Three new genera of Odontopygidae from the Udzungwa Mountains, Tanzania (Diplopoda, Spirostreptida, Odontopygidae). European Journal of Taxonomy 221: 1-17. https://doi.org/10.5852/ejt.2016.221

Enghoff H. 2017a. A new East African genus of spirostreptid millipedes (Diplopoda, Spirostreptida, Spirostreptidae), with notes on their fungal ectoparasite Rickia gigas. Zootaxa 4273 (4): 501-530. https://doi.org/10.11646/zootaxa.4273.4.3

Enghoff H. 2017b. A new species of the Chaleponcus dabagaensis-group from Mount Rungwe, Tanzania - support for an extended concept of the Eastern Arc Mountains (Diplopoda, Spirostreptida, Odontopygidae). Zootaxa 4353: 389-392. https://doi.org/10.11646/zootaxa.4353.2.11

Enghoff H. \& Frederiksen S.B. 2015. A mountain of millipedes II: The genus Aquattuor Frederiksen, 2013 - five new species from the Udzungwa Mountains and one from Mt. Kilimanjaro, Tanzania (Diplopoda, Spirostreptida, Odontopygidae). European Journal of Taxonomy 150: 1-25.

https://oi.org/10.5852/ejt.2015.150

Enghoff H., Golovatch S., Short M., Stoev P. \& Wesener T. 2015. Diplopoda - taxonomic overview. In: Minelli A. (ed.) The Myriapoda 2. Treatise on Zoology - Anatomy, Taxonomy, Biology: 363-453. Brill, Leiden, Boston.

Enghoff H., Hoffman R.L. \& Howell K.M. 2016. Checklist of the millipedes (Diplopoda) of Tanzania. Journal of East African Natural History 105 (1): 51-113. https://doi.org/10.2982/028.105.0103

Enghoff H., Jensen L.M. \& Mikhaljova E.V. 2017. A new genus of mongoliulid millipedes from the Far East of Russia. With a list of species in the family (Diplopoda, Julida, Mongoliulidae). European Journal of Taxonomy 326: 1-19. https://doi.org/10.5852/ejt.2017.326

Farfan M.A. \& Klompen H. 2012. Phoretic mite associates of millipedes (Diplopoda, Julidae) in the northern Atlantic region (North America, Europe). International Journal of Myriapodology 7: 62-91. https://doi.org/10.3897/ijm.7.3064

Frederiksen S.B. 2013 East African odontopygid millipedes 3: Two new genera; Lamelloramus and Aquattuor proposed to contain three new species (Diplopoda; Spirostreptida; Odontopygidae). Zootaxa 3694 (1): 59-66. https://doi.org/10.11646/zootaxa.3694.1.4

Fusco G., Brena C. \& Minelli A. 2000. Cellular processes in the growth of lithobiomorph centipedes (Chilopoda: Lithobiomorpha). A cuticular view. Zoologischer Anzeiger 239: 91-102.

Hoffman R.L. 1963. A new diplopod of the genus Spinotarsus from Tanganyika. Opuscula Zoologica München 69: 1-4.

Hoffman R.L. 2000. On the generic position of Spinotarsus caboverdus (Spirostreptida: Odontopygidae). Myriapodologica 6 (10): 87-94. Available from https://biodiversitylibrary.org/page/52250124 [accessed 27 Nov. 2017].

Kraus O. 1960. Äthiopische Diplopoden I. Monographie der Odontopygidae-Odontopyginae (Diplopoda, Spirostreptoidea). Annalen van het Koninklijk Museum van Belgisch-Congo 82: 1-207.

Kraus O. 1966. Phylogenie, Chorologie und Systematik der Odontopygoideen (Diplopoda, Spirostreptomorpha). Abhandlungen der Senckenbergischen naturforschenden Gesellschaft 512: 1-143.

Marshall A.R., Jørgensbye H.I.O., Rovero F., Platts P.L., White P.C.L. \& Lovett J.C. 2010. The speciesarea relationship and confounding variables in a threatened monkey community. American Journal of Primatology 72: 325-336. https://doi.org/10.1002/ajp.20787

Peters W.C.H. 1855. Über die Myriapoden im allgemeinen und insbesondere über die in Mossambique beobachteten Arten. Monatsberichte der Königlich Preußischen Akademie der Wissenschaften zu Berlin 14: $75-85$. 
Peters W.C.H. 1862. Naturwissenschaftliche Reise nach Mossambique auf Befehl seiner Majestät des Königs Friedrich Wilhelm IV in den Jahren 1842 bis 1848 ausgeführt. Zoologie. V. Insecten und Myriapoden. Georg Reimer, Berlin. Available from https://biodiversitylibrary.org/page/33195016 [accessed 27 Nov. 2017].

Pocock R.I. 1896. On the scorpions, centipedes, and millipedes obtained by Dr. Gregory on his expedition to Mount Kenia, East Africa. Annals and Magazine of Natural History, Series 6, 17: 425-444. https://doi.org/10.1080/00222939608680394

Seeman O.D. \& Nahrung H.F. 2000. Mites as fungal vectors? The ectoparasitic fungi of mites and their arthropod associates in Queensland. Australasian Mycologist 19 (1): 3-9.

Tavares I.I. 1985. Laboulbeniales (Fungi, Ascomycetes). Mycologia Memoir 9. J. Cramer, Braunschweig, Germany.

Verhoeff K.W. 1901. Über die Gonopoden von Odontopyge und eine n. sp. d. G. Zoologischer Anzeiger 24 (656): 665-672. Available from https://biodiversitylibrary.org/page/9745626 [accessed 27 Nov. 2017].

Manuscript submitted: 9 May 2017

Manuscript accepted: 26 June 2017

Manuscript published: 11 January 2018

Topic editor: Rudy Jocqué

Desk editor: Danny Eibye-Jacobsen

Printed versions of all papers are also deposited in the libraries of the institutes that are members of the EJT consortium: Muséum national d'Histoire naturelle, Paris, France; Botanic Garden Meise, Belgium; Royal Museum for Central Africa, Tervuren, Belgium; Natural History Museum, London, United Kingdom; Royal Belgian Institute of Natural Sciences, Brussels, Belgium; Natural History Museum of Denmark, Copenhagen, Denmark; Naturalis Biodiversity Center, Leiden, the Netherlands; Museo Nacional de Ciencias Naturales-CSIC, Madrid, Spain; Real Jardín Botánico de Madrid CSIC, Spain. 